NBER WORKING PAPER SERIES

\title{
DO LOCAL ELECTIONS IN NON-DEMOCRACIES INCREASE ACCOUNTABILITY? EVIDENCE FROM RURAL CHINA
}

\author{
Monica Martinez-Bravo \\ Gerard Padró i Miquel \\ Nancy Qian \\ Yang Yao \\ Working Paper 16948 \\ http://www.nber.org/papers/w16948
}

\section{NATIONAL BUREAU OF ECONOMIC RESEARCH \\ 1050 Massachusetts Avenue}

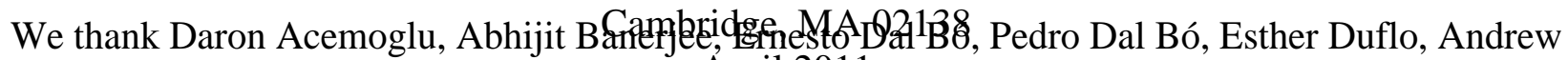
Foster, Peter Lorentzen, Dilip Mookherjee, Kêtmrib²Btien, Rohini Pande, Ben Olken, Elizabeth Perry, Scott Rozelle, Lily Tsai, and Eric Weese for their insights; the participants of the Yale Development Seminar, the University of Lausanne applied seminar, the Chinese University of Hong Kong applied seminar, Yale ISPS Workshop, Ohio State University Agricultural Economics Seminar, Brown Macro Lunch and MIT Development Lunch, CEPR Development Conference in Barcelona, the conference on Endogenous Institutions and Conflict at UC Berkeley, the NEUDC (MIT), the China Summer Institute, NBER China for useful comments; Carl Brinton, Alex Cohen, Louis Guilbert, Ting Han, Ang Sun, Jing Tao, Yiqing Xu, Jaya Wen, Xiaoxue Zhao and Ben Zou for excellent research assistance; and Jeff Blossom and Giovanni Zambotti at the Harvard CGA for GIS assistance. We are extremely grateful to the Chinese Ministry of Agriculture RCRE for sharing their data, and especially to Zhigang Wu and the teams in Gansu and Shanxi for guiding our pilots, interviews and focus groups. We also thank John Giles for sharing his extensive knowledge and documentation of the RCRE NFS dataset with us and Scott Rozelle for his intellectual generosity. We acknowledge financial support from Brown University PSTC, Stanford GSB Center for Global Business and the Economy, Harvard Academy Scholars Research Grant and the National Science Foundation Grant 079643. The views expressed herein are those of the authors and do not necessarily reflect the views of the National Bureau of Economic Research.

NBER working papers are circulated for discussion and comment purposes. They have not been peerreviewed or been subject to the review by the NBER Board of Directors that accompanies official NBER publications.

(C) 2011 by Monica Martinez-Bravo, Gerard Padró i Miquel, Nancy Qian, and Yang Yao. All rights reserved. Short sections of text, not to exceed two paragraphs, may be quoted without explicit permission provided that full credit, including $(\odot$ notice, is given to the source. 
Do Local Elections in Non-Democracies Increase Accountability? Evidence from Rural China Monica Martinez-Bravo, Gerard Padró i Miquel, Nancy Qian, and Yang Yao

NBER Working Paper No. 16948

April 2011

JEL No. H4,P16

\section{ABSTRACT}

We use unique survey data to study whether the introduction of local elections in China made local leaders more accountable towards local constituents. We develop a simple model to predict the effects on different policies of increasing local leader accountability, taking into account that there is an autocratic upper government. We exploit variation in the timing of the top-down introduction of elections across villages to estimate the causal effects of elections and find that elections affected policy outcomes in a way that is consistent with the predicted effects of increased local leader accountability.

Monica Martinez-Bravo

John Hopkins University

1717 Massachusetts Ave, NW

Washington D.C., 20036

mmb@jhu.edu

Gerard Padró i Miquel

STICERD

London School of Economics

Houghton Street

London, WC2A 2AE

UNITED KINGDOM

and NBER

g.padro@1se.ac.uk
Nancy Qian

Department of Economics

Yale University

27 Hillhouse Avenue

New Haven, CT 06520-8269

and NBER

nancy.qian@yale.edu

Yang Yao

China Center for Economic Research

Peking University

Peking, China

yyao@ccer.pku.edu.cn 


\title{
Do Local Elections in Non-Democracies Increase Accountability? Evidence from Rural China*
}

\author{
Monica Martinez-Bravo ${ }^{\dagger}$ Gerard Padró i Miquel; \\ Nancy Qian̊and Yang Yao
}

4/12/2011 (First Version: 9/1/2007)

\begin{abstract}
We use unique survey data to study whether the introduction of local elections in China made local leaders more accountable towards local constituents. We develop a simple model to predict the effects on different policies of increasing local leader accountability, taking into account that there is an autocratic upper government. We exploit variation in the timing of the top-down introduction of elections across villages to estimate the causal effects of elections and find that elections affected policy outcomes in a way that is consistent with the predicted effects of increased local leader accountability.

Keywords: Institutions, Elections, Leader Accountability, Local Democracy, Public Goods.
\end{abstract}

\section{Introduction}

Many developing countries have local elections despite having autocratic central regimes. ${ }^{1}$ For example, local elections have occurred in Indonesia under Suharto (1968-1998), Brazil during the

\footnotetext{
${ }^{*}$ We thank Daron Acemoglu, Abhijit Banerjee, Ernesto Dal Bó, Pedro Dal Bó, Esther Duflo, Andrew Foster, Peter Lorentzen, Dilip Mookherjee, Kevin O’Brien, Rohini Pande, Ben Olken, Elizabeth Perry, Scott Rozelle, Lily Tsai, and Eric Weese for their insights; the participants of the Yale Development Seminar, the University of Lausanne applied seminar, the Chinese University of Hong Kong applied seminar, Yale ISPS Workshop, Ohio State University Agricultural Economics Seminar, Brown Macro Lunch and MIT Development Lunch, CEPR Development Conference in Barcelona, the conference on Endogenous Institutions and Conflict at UC Berkeley, the NEUDC (MIT), the China Summer Institute, NBER China for useful comments; Carl Brinton, Alex Cohen, Louis Guilbert, Ting Han, Ang Sun, Jing Tao, Yiqing Xu, Jaya Wen, Xiaoxue Zhao and Ben Zou for excellent research assistance; and Jeff Blossom and Giovanni Zambotti at the Harvard CGA for GIS assistance. We are extremely grateful to the Chinese Ministry of Agriculture RCRE for sharing their data, and especially to Zhigang Wu and the teams in Gansu and Shanxi for guiding our pilots, interviews and focus groups. We also thank John Giles for sharing his extensive knowledge and documentation of the RCRE NFS dataset with us and Scott Rozelle for his intellectual generosity. We acknowledge financial support from Brown University PSTC, Stanford GSB Center for Global Business and the Economy, Harvard Academy Scholars Research Grant and the National Science Foundation Grant 079643.

${ }^{\dagger}$ Johns Hopkins, SAIS: mmb@jhu.edu

${ }^{\ddagger}$ London School of Economics, NBER, BREAD, CEPR: g.padro@lse.ac.uk

$\S$ Corresponding author - Yale University, NBER, BREAD, CEPR: nancy.qian@yale.edu

`CCER at PKU: yyao@ccer.pku.edu.cn

${ }^{1}$ See Gandhi and Lust-Okar (2009) for a recent literature review on elections in autocratic regimes.
} 
military dictatorship (1964-1985) and Mexico under the PRI (1929-2000). Recently, local elections were also introduced in Vietnam in 1998, in Yemen in 2001 and in Saudi Arabia in 2005. China, which introduced elections at the village level starting in the 1980s, is a primary example. Despite the fact that these institutional arrangements affect the lives of millions of people worldwide, we have little evidence on whether or how they matter. The cross-country empirical literature typically focuses on comparisons of clusters of institutions at the national level. ${ }^{2}$ The few within-country empirical studies on local democratic institutions are typically set in the context of democratic regimes and study particular aspects of local elections rather than the effect of the introduction of elections. ${ }^{3}$ Theoretical predictions of the effect of introducing local democracy within an authoritarian regime are ambiguous. On the one hand, providing citizens with the capacity to hold local leaders accountable should improve leader performance. ${ }^{4}$ On the other hand, autocratic regimes may not have the incentives to implement proper electoral procedures, which could weaken accountability. Moreover, even if elections are procedurally sound, the elected leaders might not have the de facto power to carry out the will of their constituents. For instance, Acemoglu and Robinson (2008) argues that institutional reforms can fail to result in significant policy changes because they are easily circumvented by the existing elites. This is a particularly pressing concern when reforms only affect the lowest level of an otherwise autocratic regime.

In this paper, we examine the effects of introducing local elections in an authoritarian regime in the context of village electoral reforms in rural China (1980-2005). During the 1980s, the regime began to introduce elections for members of the village committee in rural areas. The most important position among these was the village chief (VC). Previously, this position was directly appointed by Chinese Communist Party (CCP) officials. The regime believed that elections would provide the $\mathrm{VC}$ with a democratic mandate, and thereby more legitimacy to implement and enforce central government directives in the village. In addition, many proponents of this reform argued that villagers would use elections to monitor and discipline village officials, who were in many cases suspected of corruption and shirking. However, opponents retorted that shifting accountability towards villagers would worsen the implementation of unpopular policies, such as the One Child Policy, and generally weaken the center's control. Therefore, to ensure that elected leaders would still be partially accountable to the CCP, the party leadership structure within villages and at all levels of government above the village remained in place. Moreover, upper levels maintained control over the process of rural democratization and increased the openness of local elections gradually. In the first electoral reform, the local CCP could nominate the candidates in the elections. This was later followed by the introduction of open nominations to the villagers. Since elections were often poorly implemented

\footnotetext{
${ }^{2}$ See for instance Mauro (1995), Barro (1996), Hall and Jones (1999), Acemoglu et al. (2001), Persson and Tabellini (2004), Mulligan et al. (2004) and Mobarak (2005).

${ }^{3}$ Several recent works study the effects of specific aspects of local democratic governance in India (e.g., Pande, 2003; and Chattopadhyay and Duflo, 2004) and Brazil (e.g., Ferraz and Finan, 2008). Amongst these studies, Foster and Rosenzweig (2004) is the one exception in studying the effects of the introduction of local elections in India. More generally, Bardhan and Mookherjee (2006) provides a review of decentralization reforms in developing countries.

${ }^{4}$ This is what the political accountability literature would predict. See the textbook by Besley (2006) for a review of the theory.
} 
and the reforms did not affect the role of the CCP in any other parts of the regime, these reforms can only be interpreted as a movement towards limited democracy.

The main goal of this study is to determine whether these electoral reforms caused the VC to become more accountable to his village constituents. Our study makes three contributions. First, we develop a model to predict the effect of increasing local leader accountability on different policies. Second, we construct a large panel data set that documents electoral policies, village political and economic structures, and policy and economic outcomes that spans over two decades. Finally, we test the predictions or model by estimating the causal effect of the introduction of elections. The empirical results, together with the predictions from our simple theoretical framework, allow us to understand the effect of elections on local leader accountability. The richness of our data allows us to explore and rule out the most likely alternative explanations for our empirical results.

Specifically, the first step towards this goal is to determine how local policies change as a result of a hypothesized change in accountability in a context where the central government remains autocratic. We develop a simple model of village policy-making with three actors: the upper government, the VC and the villagers. In the model, the introduction of electoral reforms changes the VC's position from being solely accountable to the upper government to being accountable to both the upper government and the villagers. In our study, this partial shift in accountability is synonymous to an increase in accountability towards villagers. We show that this shift in accountability has different effects on policy outcomes depending on the amount of discretion the village government has over the policy and the congruence of preferences between the upper government and the villagers.

This provides us with a useful typology of policies that guides our empirical analysis and inference of changes in accountability. Type I policies are under the discretion of the VC and for which the upper government and villagers have conflicting preferences over them. For these policies, a partial shift in accountability in favor of villagers will obviously cause the $\mathrm{VC}$ to implement policies that are closer to the villagers' preferences. Type II policies are also under the discretion of the VC, but for which there is no obvious conflict of interest between villagers and upper levels of government. The effects of increasing accountability towards villagers on these policies are less obvious because there is no disagreement between villagers and the upper government. Our model shows that an increase in accountability will cause Type II policies to move towards the preferences of villagers only if the VC suffers a cost of implementation (e.g., cost of effort or lost rents) and the villagers are better than the upper government at monitoring the VC. Type III policies are beyond the discretion of the VC. A shift in accountability should have no effect on such policies.

Finding that the introduction of elections causes Type I policies to change in favor of villagers implies that the reforms effectively shifted accountability. Finding a similar effect on Type II policies is a sign that the villagers are better monitors of VCs than upper levels of government. Type III policies serve as placebo tests. If the introduction of elections only affects $\mathrm{VC}$ accountability and is not correlated with other policy changes, then we expect to find that elections have no effect on Type III policies.

One of the key advantages of the Chinese context is that there is a rich set of policies for which 
the discretion of the $\mathrm{VC}$, the amount of effort from the $\mathrm{VC}$ that is required for implementation, and the preferences of the upper government and villagers are well-understood. Therefore, we can map the theoretical typology into observable policy outcomes. Type I policies include the One Child Policy and upper-government expropriation of land, both of which are extremely unpopular with villagers and can be partially influenced by the VC. Type II policies include within-village public goods provision and within-village land allocation. Both are costly to the $\mathrm{VC}$ in terms of effort and there is no major conflict of interest between villagers and upper governments. Type III policies include the location of secondary schools and the provision of central government special aid for households below the national poverty line. The village government takes no part in the decisions on either of these policies. We discuss these policies and how they fit the typology in detail in the paper.

Lack of data has posed a serious barrier for studies of Chinese electoral reforms. Recently, researchers such as Scott Rozelle have begun to compile large cross sections of detailed data on village economic and political variables. ${ }^{5}$ However, to fully capture the effects of the introduction of elections, we need a large panel of villages. Moreover, we need systematic data on the political power structure within villages and the policy outcomes that we describe above. One important contribution of this study is to provide such data. We document the history of political reforms, policies, public investments and the powers of village leaders by conducting a large retrospective survey of over two hundred villages that covers the years 1980-2005. We match this survey to annual economic data collected by the Ministry of Agriculture during 1987-2005, forming a unique village-level panel of political, economic and social variables that we use for our empirical analysis. To the best of our knowledge, these data provide the most comprehensive record of the political reform history of Chinese villages in terms of geographic and temporal scope.

Using these data, we estimate the causal effect of elections on village-level outcomes by exploiting differences in the timing of their introduction across villages. Timing was decided by the upper levels of government, with little input from villages. To retain control, the upper government is known to have delayed introducing elections in villages with a history of non-compliance with central policies. No other pattern has emerged from either our data, the existing literature, or interviews that the authors of this paper conducted with officials from various levels of the Chinese government. Since "problematic" villages are few in number, our main empirical strategy assumes that the timing of the elections is quasi-random for villages within a province. We later relax this assumption and check that our estimates are not driven by endogenous timing in the introduction of elections. Our main strategy is similar in spirit to a differences-in-differences (DD) strategy where we compare the outcomes of villages that have had their first election to villages in the same province which have not yet introduced elections: village fixed effects control for all time-invariant differences between villages, such as distance to a city; year fixed effects control for all changes over time that affect regions similarly, such as nationwide policy changes; and province-time trends allow us to control

\footnotetext{
${ }^{5}$ Scott Rozelle and a team of researchers from the Center for Chinese Agricultural Policy in Beijing have thus far produced two detailed studies on elections, fiscal reforms and village pubic goods investment from their data. See Luo et al. (2007, 2010).
} 
for all differential changes across provinces which are broadly linear. Controlling for province-time trends is important given the divergence in economic growth across China during this period.

Our empirical analysis begins by documenting that VCs had de facto power to make policy decisions. Then we examine the impact of elections on policy outcomes. First, we find that the introduction of elections reduced the incidence of upper-government expropriation of village land and the enforcement of the One Child Policy. Hence, elections shift Type I policies in favor of villagers, which imply that elections increased the VC's accountability towards villagers. Second, we find that elections increased household land allocation and improved village public goods investment. In particular, elections increased public investment in schooling for villages with many schoolage children and increased public investment in irrigation for villages that are heavily dependent on agriculture. Therefore, elections also shift Type II policies towards the preferences of villagers. Under our framework, this implies that villagers are better than the upper government at monitoring the VC. Finally, we find that elections had no effect on upper-government special aid or the distance to secondary schools, i.e., Type III policies. These results provide strong evidence that our results reflect a change in the VC's accountability rather than confounding factors, such as simultaneous policy changes at higher levels of government. Consistent with this, we find that the increase in public investment is entirely driven by funding raised from villagers; elections had no effect on public goods funding from upper-government sources.

It is worth noting that our results reflect the introduction of the first election and that we find no evidence of additional effects from the subsequent introduction of open nominations. This suggests that the main mechanism behind our results is more likely to be the change in the incentives for VCs rather than the villagers' ability to select their favored candidates. ${ }^{6}$

The causal interpretation of our estimates requires the assumption that the timing of the introduction of elections was not correlated with other factors which may have influenced the outcomes of interest. It seems unlikely that other factors can generate the same effects as a shift in leader accountability for the large set of outcomes that we examine but leave our placebo policies unchanged. However, to be cautious, we present a detailed discussion of potential caveats and address them in the section on robustness.

The results of this study are important for policy makers and researchers in development economics and political economy. They show that a limited movement towards democracy can generate significant improvements for the population, even if the overall authoritarian structure of the regime does not change. Moreover, our results provide support for policies that aim to improve local governance in developing countries by harnessing the ability of citizens to monitor local officials.

This paper contributes to a number of different literatures. First, we add valuable within-country evidence to the cross-country literature on the relationship between political institutions and policy outcomes. Second, we contribute to the growing body of work on the role of local governance in developing countries. In particular, we build on the increasing number of empirical studies on

\footnotetext{
${ }^{6}$ This interpretation is subject to the caveat that it assumes that the CCP was not always selecting candidates that were the most preferred by the villagers. See the discussion in section 3 .
} 
re-election incentives (e.g., Besley and Case, 1995; DalBó and Rossi, 2008; de Janvry et al., 2010; Ferraz and Finan, 2011) and on the effect of information on electoral accountability (e.g., Besley and Burgess, 2002; Ferraz and Finan, 2008; Bobonis et al., 2010; and Banerjee et al., 2010). ${ }^{7}$ Our work is also closely related to Björkman and Svensson (2009), which studies the effect of citizen monitoring on local-government public goods provision, and Foster and Rosenzweig (2004), which finds that the introduction of the panchayat system in India improved the provision of public goods. Our finding that elections improve public goods provision in China is consistent with these previous studies. Also, the implication that villagers are better than upper levels of government at monitoring village leaders is similar to the findings of Björkman and Svensson (2009). However, the nature of China's strong autocratic state and the mechanisms driving our results are very different from these earlier works. ${ }^{8}$ To the best of our knowledge, the only existing empirical studies of democratic local governance within authoritarian regimes examine China's village elections. These studies use cross-sectional data or relatively small samples of village panels and find that elections can reduce inequality and increase the overall level of public goods provision (e.g., Gan et al., 2007; Luo et al., 2007, 2010; Shen and Yao, 2008; Zhang et al., 2004). ${ }^{9}$ We differ from these earlier works in our focus on inferring the effect of local elections on leader accountability within an autocratic regime. We contribute to existing works on Chinese elections by providing a coherent framework that has predictions on a broad set of outcomes, which we can test using data that are richer and cover more years and regions than the existing datasets used in previous works.

This paper is organized as follows. Section 2 describes the background of Chinese villages and the electoral reforms. Section 3 presents the conceptual framework. Section 4 describes the main empirical strategy and Section 5 describes the data. Section 6 presents our main empirical findings and Section 7 examines the robustness checks. Section 8 offers concluding remarks.

\footnotetext{
${ }^{7}$ Bobonis et al. (2010) and Ferraz and Finan (2008) find that the information released by audits affects electoral governance and performance. (For a study of the effect of upper-government audits versus citizen monitoring, also see Olken (2007)). Besley and Case (1995), Ferraz and Finan (2011) and de Janvry et al. (2010) compare elected officials who face term limits with those who do not, DalBó and Rossi (2008) study the effect of term length on effort in Argentina. Our findings also provide valuable empirical evidence for understanding the differences in incentives and performance between appointed and elected officials. This literature has mostly been theoretical - e.g., Besley and Coate (2003), Maskin and Tirole (2004) and Alesina and Tabellini (2007, 2008)

${ }^{8}$ In terms of mechanisms, we are examining the effect of a set of mechanisms embodied in the formal institution of elections. In contrast, Björkman and Svensson (2009) focuses on citizen monitoring, which is only one of the many mechanisms included in elections. Foster and Rosenzweig (2004) focus on party competition, which is unlikely to play a role in China's one-party context.

${ }^{9}$ There are a number of other related studies on Chinese elections (e.g., Rozelle and Boisvert, 1994, 1995; Oi and Rozelle, 2000; Kennedy et al., 2004; Brandt and Turner, 2007; Mu and Zhang, 2011). Amongst studies of rural China, our examination of land expropriation and allocation is also closely related to two recent articles on land tenure in rural China (Rozelle and Li, 1998; Jacoby et al., 2001). In a related context Martinez-Bravo (2010) studies the implications of different local governance structures in Indonesia under Suharto in the persistence of patronage networks and voter manipulation in the first democratic election.
} 


\section{Background}

\subsection{The Village Government}

Villages are the lowest level of administration in rural China. Village governments were first organized by the communist government during the early 1950s, with two groups of leaders in each village. The VC, also referred to as the village "chief," "head" or "chairman," leads a village committee that typically comprises three to five members. The second group of leaders are the CCP village branch. They are led by the village party secretary (henceforth PS). Before elections were introduced, all these positions were filled by appointment by the county government and village party branch. ${ }^{10}$ On average, there are approximately 400 households per village. The village government is extremely important for the well-being of its citizens because it implements policies mandated by the central-government within the village and takes many important village level decisions, such as public goods provision and land allocation (e.g., Oi and Rozelle, 2000; Rozelle and Boisvert, 1994, Brandt and Turner, 2007; Whiting, 1996).

\section{$2.2 \quad$ Electoral Reforms}

The first local elections were introduced in the early 1980s soon after the fall of the commune system. The primary motive for introducing local elections was to improve the enforcement of centrally mandated policies at the village level. Proponents of reform claimed that elected village leaders would have more legitimacy and would better distribute the burden of these policies, which would increase overall compliance. It was also hoped that local leaders with a democratic mandate would better determine which public good investments were necessary and would better facilitate the local coordination necessary for providing them (e.g., O'Brien, 1994; Kelliher, 1997; O'Brien and $\mathrm{Li}, 1999)$.

In addition, advocates of reform argued that village elections would reduce the need for the central government to closely monitor local officials, which was difficult in a geographically vast and heterogeneous country. This concern has been endemic in the centrally planned regime since its conception in 1949, and had been exacerbated by the widening regional differences caused by post-Mao market reforms. Imperfect monitoring meant that many local cadres were suspected of corruption and shirking, which generated intense discontent and discredited the regime in rural China. The hierarchical structure not only observed the actions of local leaders imperfectly, but also faced the difficulty of knowing the preferences and needs of each locality. ${ }^{11}$ The introduction of local elections

\footnotetext{
${ }^{10}$ The Chinese government, led by the Chinese Communist Party (CCP), is broadly ordered in a vertical hierarchy, from the central government in Beijing down to the rural levels that comprise counties and townships. According to the National Statistical Yearbooks, rural population decreased from approximately $83 \%$ of total population in 1980 to approximately $75 \%$ by 2000 . Today, there are 31 provincial units (which include autonomous regions and city-level municipalities), governing 2,872 counties, which contain 14,677 townships and 623,669 rural villages (as defined by the number of village governments, cunming weiyuanhui). This means that the average county government supervises approximately 5 townships and 217 villages.

${ }^{11}$ See Meng et al. (2010) for a study of the role that information problems can play in a centrally planned regime in the context of China's Great Famine.
} 
was seen as a potential solution to this problem because it shifted the monitoring responsibilities onto villagers. Proponents argued that making local leaders accountable to villagers would impose checks on the VC's behavior and would also allow villagers to select the most competent candidates (Kelliher, 1997). The latter may have been particularly relevant to the Chinese context since village leaders almost invariably came from within the same village.

"Who supervises rural cadres? Can we supervise them? No, not even if we had 48 hours a day...." - Peng Zhen, vice-chairman of the NPC Standing Committee, said at the chairmanship meeting of the Standing Committee of the Sixth NPC, April 6, 1987 (O’Brien and Li, 1999).

Opponents, however, retorted that shifting accountability towards villagers would disrupt the implementation of unpopular policies, such as the One Child Policy, and generally weaken hierarchical control in an increasingly heterogeneous country. In particular, regional governments voiced concerns about the effect of elections in two types of "problematic" villages: those that were already resisting unpopular policies and those that were dominated by a large kinship clan. ${ }^{12}$

These potential costs were taken into account when designing the electoral reforms. The main thrust of the reform was to allow the $\mathrm{VC}$ and the village committee to be elected by the villagers instead of appointed by the regional CCP. VCs were to be elected for three-year terms with no stipulated term limits. However, to ensure that village leaders would still be partially accountable to the CCP, there was no change in the selection method of the members of the village CCP branch and PS positions, who continued to be appointed. Moreover, the upper government maintained tight control of the democratization process and only gradually increased openness. Initially, the regional $\mathrm{CCP}$ nominated the candidates but was required by law to nominate at least two of them per position. Only in a second wave of reforms were nominations opened to all villagers. This is commonly referred to as haixuan.

Elections were introduced in a top-down fashion by the provincial and county governments. Once the provincial government decided to implement village elections, almost all villages within that province followed within a few years (O'Brien and Li, 1999). By all accounts, villages had little discretion over the timing of introduction of elections, which is characteristic of reforms in rural China.

"These [elections] should not be interpreted as bottom-up initiatives by the villagers themselves; they are not in a position to play any precedent-setting part in the initiation of new electoral reforms. There is a mistaken belief among some people outside China regarding this... elections are quietly being instituted at levels above the village, engineered first in selected districts at a distance from Beijing, through the connivance of the [central] Ministry of Civil Affairs and middle-ranking officials out in the regions."

\footnotetext{
${ }^{12}$ In the latter case, the concern was that the elected position would be captured by the dominant clan, which would then implement policies for the benefit of its clan members at the cost of other villagers (O'Brien and Li, 2006: Ch. 3).
} 
— Unger (2002, p. 222). ${ }^{13}$

Several innovative provincial governments began to experiment with elections in the early 1980s. After some debate within the CCP, village elections were formally codified by the central government in the Organizational Law on Village Committees (henceforth OLVC) in 1987. From this point onwards, all provinces were pushed to introduce elections for all rural areas. Finally, a revision of the OLVC in 1998 made elections of VCs mandatory and required candidate nominations to be open to all villagers.

The top-down process of introducing elections means that differences in timing across villages are largely driven by the upper governments' preferences of where to first introduce elections. According to anecdotal and qualitative evidence, the main determinant seems to have been the desire to delay elections in the "problematic" villages that we discussed earlier (e.g., Oi and Rozelle, 2000; Li, 2009).

There are several additional facts to keep in mind for the empirical analysis. First, the relative powers of the VC and the PS were never clarified. ${ }^{14}$ For this reason, one of the contributions of our survey is to document the de facto power of each leader. Second, in these elections, there are no political parties and no slates of candidates with common platforms. Candidates are typically wellknown by the villagers as they are from the same village. As a consequence, candidates typically run on well-understood issues and are probably selected for qualities that are observable on a daily basis. ${ }^{15}$ Finally, it is important to note that the electoral procedures varied greatly in quality and in many cases were seriously subverted. For instance, some of the first elections only had as many candidates as the number of positions to be filled and were therefore non-competitive, i.e., the CCP appointed only one candidate per position. Our survey documents these aberrations in election quality, which allows us to examine and control for them in the empirical analysis. ${ }^{16}$ The next section discusses the implications of these non-competitive elections for the interpretation of our results.

\section{Conceptual Framework}

The main goal of this paper is to understand whether the introduction of local elections in China was effective in making VCs more accountable to villagers. This is far from obvious considering their imperfect implementation and the continued supervisory role of the CCP. Moreover, the village government has responsibilities over a range of policies, and it is unclear ex-ante how an increase in the accountability of the village government towards the villagers affects each policy outcome.

\footnotetext{
${ }^{13}$ Unger (2002) notes the general passivity of villages in implementing rural reforms in his study of land reforms and the adoption of the Household Responsibility Reform during the mid 1980s.

${ }^{14}$ In fact the second OLVC stated that village decisions were to be taken by the VC and village committee under the "guidance" of the CCP Branch. This vagueness led to disputes and encroachment by the PS and county government on the independence of the VC (e.g., Oi and Rozelle, 2000; Guo and Bernstein, 2004).

${ }^{15}$ There are very few accounts of actual electoral campaigning. In many cases, elections were set up with only a few days' notice (Unger, 2002: p. 221).

${ }^{16}$ There were also other aberrations in electoral procedures. We document and control for these in our analysis later in the paper. See section 5.
} 
To shed light on this issue, we develop a simple model of political accountability in the context of an overall authoritarian regime and illustrate the effects of an increase in accountability towards villagers on different types of policies. Then, we discuss the policy outcomes that we can observe in the data and how they map into our conceptual framework. Finally, we discuss the potential mechanisms underlying the change in accountability and the extent to which our analysis will be able to distinguish their role in driving our main results.

\subsection{The Effect of a Partial Shift in Accountability}

We develop a simple model of political accountability in the context of an overall authoritarian regime and illustrate the effects of an increase in accountability towards villagers on different types of policies. This model is presented formally in the Appendix. In this section, we provide an intuitive discussion.

We adapt a standard accountability model to the rural Chinese context, where there are three actors: the upper government, the village government (which we simply think of as the village chief VC) and the villagers. Within this model, we examine the effect of a shift in the accountability of the VC. Before elections, he is solely accountable to the upper government. Afterwards, he is accountable to both the upper government and the villagers. In our context, increasing accountability towards the villagers is equivalent to a shift in accountability away from the upper government towards the villagers. Our model distinguishes between three types of policies according to whether the VC has any discretion in enforcement, the preferences of the upper government and villagers over the policy outcomes, and the amount of disutility incurred by the VC in the implementation of the policy. We categorize policies into three types.

The first type (Type I) comprises policies that the VC can influence and for which villagers and the upper government have opposing preferences. The model predicts that a shift in accountability moves these types of policies towards the preferences of villagers. This provides a simple test for a shift in accountability.

For the second type of policies (Type II), villagers and upper government officials share similar preferences, the $\mathrm{VC}$ has discretion over the policies and he suffers a cost of implementation. If implementing these policies was costless to the $\mathrm{VC}$, he would cater to the preferences of villagers and upper government independently of the direction of accountability. However, since the policy is costly to the VC (in terms of effort or loss of rents), he will try to shirk. In this case, making the $\mathrm{VC}$ accountable to villagers will shift policies towards the preferences of villagers only if villagers are better than the upper government at monitoring and restraining village officials. A change in these policies is therefore a sign of a monitoring advantage on the part of villagers.

The third type of policies (Type III) are those that are beyond the control of the village government. A shift in accountability should have no effect in such cases.

In the empirical analysis, we will test the hypothesis that the introduction of elections increased the VC's accountability by investigating whether elections shifted Type I policies towards the preferences of villagers. We test the additional hypothesis that villagers are better at monitoring VCs 
than the upper government by investigating whether elections also shifted Type II policies towards the preferences of villagers. Type III policies serve as placebos in the empirical analysis. In other words, we check that the effects of Types I and II policies are driven by a change in the VC's accountability rather than other spurious factors by checking that elections do not affect Type III policies. Note that our interpretation need not assume that village leaders have much discretion over Types I and II policies or that they have absolutely no discretion over Type III policies. Rather, we only need to assume that village governments have relatively more discretion over the first two types of policies.

\subsection{Observable Policy Outcomes}

The policy outcomes we examine are the following:

TYPE I: The One Child Policy (OCP) and village land expropriation by the upper government are two extremely unpopular with villagers and for which the VC has some discretion in enforcement. The OCP, which began in 1979-80, restricts families to have only one child and is the central government's main instrument for reducing fertility. However, in order to prevent female infanticide (due to the strong boy preference in rural China), the government also allows exemptions in special circumstances. One common exemption is to allow households to have a second child if the first is a girl. This is outlined in State Council Document No. 7, which was published by the central government in 1984. However, since the central government continued to pressure regional leaders to minimize fertility and did not specify when the exemption should be applied, there is built-in ambiguity that allows some degree of local discretion. In practice, while these formal exemptions are granted at upper levels of government, de facto enforcement of the One Child Policy (e.g., persuading parents to have abortions of higher parity pregnancies, monitoring illegal births and administering fines) is carried out at the village level. Moreover, village leaders are the ones that lobby the upper government for formal exemptions. Therefore, village leaders can influence the enforcement of the One Child Policy by choosing the amount of effort they exert in lobbying upper governments versus the amount of effort expended in monitoring and persuading village parents to have fewer children. This room for discretion at the village level is consistent with the observed variation in the implementation of the One Child Policy (e.g., the conditions for which parents are allowed multiple children) across villages. ${ }^{17}$

Upper-government expropriations of village land are typically related to laws of eminent domain for the construction of infrastructure and the geographic expansion of cities and townships. However, they are always highly contentious as they result in the permanent loss of farmland to villagers (Bernstein and Lu, 2003; Cai, 2003; Guo, 2001; O'Brien and Li, 1999). ${ }^{18}$ As with the One Child Policy, the village government can attempt to prevent or delay expropriation by lobbying the upper-

\footnotetext{
${ }^{17}$ This is true within provinces and even within counties. This variation is present both in our survey data and in the data on village-level family planning policies reported by the China Health and Nutritional Surveys. These statistics are available upon request.

${ }^{18}$ By law, villagers are financially compensated for the expropriated land. However, compensation is often inadequate in practice.
} 
level government. It can also organize villagers to peacefully resist. ${ }^{19}$

TYPE II: The provision of village-level public goods, such as primary schools and irrigation, and within-village land allocation are policies for which the upper government does not have strong preferences over. However, the upper government values political stability and hence wants this policies to satisfy villagers' needs. Therefore, it arguably agrees with the preferences of villagers. In contrast, providing the optimal level and composition of public goods and allocating land requires significant effort from the village leader and can reduce rent-seeking opportunities. For example, less accountable VCs may shirk in their responsibilities, underprovide useful public goods and keep too much land under the direct control of the village. ${ }^{20}$

Public goods are mostly financed with funds from the village, supplemented with a smaller amount of funds from the upper levels of government. The VC needs to raise the required funds and determine the correct object for investment. ${ }^{21}$ The VC has very little discretion over funds from the upper government, but has significant control over within village funding. Therefore, the latter should be more responsive to a change in the VC's accountability than funding from the upper government.

All land is publicly owned in China. Households are granted long term land contracts. The allocation of such contracts is one of the main responsibilities of village leaders. It is a contentious issue in rural areas, where the average household farms are approximately five $m u$ (one mu is approximately $1 / 15$ th of a hectare). A small increase in land can be extremely valuable (Unger, 2002; p.145). There are two types of land reallocations in rural China. The first type includes largescale reallocations which affect a significant proportion of households in the village. The second type includes smaller-scale reallocations (e.g., marginal adjustments for a few households, typically due to changes in household size). Our study focuses on the latter because they occur with higher frequency and because village leaders have more discretion over them as they receive relatively little attention from upper levels of government. A small fraction of village land is retained under the direct control of the village government so that the second type of land adjustment can take place without village-wide disruptions. Land that is directly controlled by the village government can be used to generate revenues for the village. This is often done by leasing land to rich village farmers or village enterprises/factories. ${ }^{22}$ In principle, the profits from these ventures are supposed to benefit all villagers. However, in practice, corrupt village leaders have been known to extract personal rents from land controlled by the village governments (Brandt and Turner, 2007; Oi and Rozelle, 2000; Rozelle and Boisvert, 1994). Therefore, increasing land allocated to households can cause village leaders additional disutility from the loss of rent-seeking opportunities.

\footnotetext{
${ }^{19}$ O'Brien and $\mathrm{Li}$ (2006: Ch 3) provides many examples of how village governments coordinate "rightful" resistance in protest against land expropriation.

${ }^{20}$ Luo et al. (2007) and Luo et al. (2010) show that, on average, village provision of public goods is very small and far from adequate. Brandt and Turner (2007) also use land control as a measure of VC rents.

${ }^{21}$ Villages typically fund most of their own public goods with profits generated by collectively owned property (e.g., village enterprises), ad hoc fees and case-by-case levies charged to households. The village government's ability to impose ad hoc fees changed towards the end of our study period when the Tax and Fee Reform (2002-03) banned the practice. We will control for this in our empirical analysis.

${ }^{22}$ There are many papers describing land use and contracts in rural China. For example, see Rozelle and Li (1998).
} 
TYPE III: Special aid and the provision of high school education are two policies that are decided entirely outside of the village. Special aid is a transfer from higher levels of government to villages that strictly depends on the number of households below the national poverty line. The provision of secondary education is decided by regional ministries of education. In practice, high schools in China are always in townships and cities and not located in villages. Note that the amount of upper-government funding for village public goods can also fall into this category of policies because the $\mathrm{VC}$ is unlikely to have much discretion over it.

\subsection{Mechanisms}

The objective of this study is to determine whether local elections in rural China effectively increased the accountability of the VC towards villagers. The political agency literature proposes two main mechanisms that voters use to hold elected politicians accountable. ${ }^{23}$ First, elections can help voters to address moral hazard problems by rewarding good performance with re-election. In this way, elections serve as means to provide the correct incentives to office holders. Second, voters can use elections to select the politicians that are more competent or whose preferences are better aligned with citizens' preferences. Recall that an important element of the debate among CCP leaders over the introduction of elections was about the capacity of elections to both control and select local officials.

It is important to note that the incentive effect of elections in rural China might be at play even if elections were not at first competitive (e.g., if the CCP nominates only one candidate per position). The introduction of elections, no matter how imperfect, signaled that the regime cared about the preferences of villagers. This encouraged villagers to demand better implementation of elections. O'Brien and $\mathrm{Li}$ (2006) documents numerous cases in which villagers, dissatisfied with the candidate(s) that the CCP nominated, appealed to province and central government officials, who investigated these concerns, recalled incumbent VCs and called for new elections. ${ }^{24}$ Therefore, even VCs elected under non-competitive elections would have expected to face competition from other candidates in the next round of elections. Hence, the desire to remain in office would have incentivized these VCs. ${ }^{25}$

The most straightforward way to separate the role of incentives from the role of better leader selection in changing policy outcomes is to compare the effect of elections in villages where elections

\footnotetext{
${ }^{23}$ This literature is large, starting with the seminal contribution of Barro (1973). For textbook treatments, see Persson and Tabellini (2000) and Besley (2006).

${ }^{24}$ For example, O'Brien documents a case in which angry crowds of villagers wanted to dismiss their village chief and protested in the township. In the end, they successfully obtained recalls, new elections were held and new VCs were elected. In yet another example, villagers complained that their elections had been manipulated with fraudulent votes and argued that the nominated candidates were corrupt. They requested the right to nominate their own candidates (this was many years before open nominations was officially introduced in 1998) but were ignored by their county government. Then, they appealed to Beijing, where the Ministry of Civil Affairs investigated, forced a recall and a new election where the villagers nominated their own candidates (O'Brien and Li, 2006: Ch. 3).

${ }^{25}$ Consistent with the belief that the introduction of elections was important even when they were not competitive, Landry et al. (2010) find that voter turn out is high even when competition is extremely limited.
} 
entailed a change in VC to villages that retained their previously appointed leader. ${ }^{26}$ Unfortunately, we lack systematic information on the VC prior to the introduction of elections. However, we can use the introduction of open nominations, which occurred after the introduction of elections for most villages, to shed some light on this question. When the CCP appoints the candidates, villagers can only select among a very restricted set. In contrast, when nominations are open, the choice set is maximized. Therefore, we can assess the importance of the selection mechanism by examining whether opening nominations enhances the effect of elections. Finding that open nominations increases the effect of elections would suggest that the selection mechanism contributed to the impact of elections. If no such effect can be found, a natural interpretation is that the selection mechanism was not important in rural China. Note that this interpretation assumes that the CCP did not always appoint the villagers' preferred candidate. ${ }^{27}$ While we believe that this is the most likely scenario, we have little concrete evidence regarding the CCP's selection criteria of nominees. The results for the effect of introducing open nominations should be interpreted with this caveat. ${ }^{28}$

\section{Empirical Strategy}

To estimate the causal effect of elections, we employ a fixed effects strategy where we control for village and year fixed effects and province-specific time trends. Village fixed effects control for all time-invariant differences between villages, such as geographic characteristics (e.g., hilliness or distance from a city), at a finer level than province fixed effects. Year fixed effects control for changes over time that affect all villages similarly (e.g., national policy changes, macroeconomic growth). Province-specific time trends control for the fact that provincial governments' decisions to introduce elections may have been driven by time-varying characteristics of the province. These time trends also allow us to control for the widening differences across regions brought about by unequal economic growth during the long time horizon of our study. Our strategy is similar in spirit to a within-province-year differences-in-differences (DD) strategy, where we compare the outcomes of villages that have had their first election to villages in the same province (and year) that have not yet implemented their first election. However, we control for province-time trends instead of the more flexible province $\times$ year fixed effects because we do not have enough variation to estimate the latter. The closeness in timing of the introduction of elections for villages within the same province means that there are many province-year cells within which there is no variation in election.

\footnotetext{
${ }^{26}$ The incentive effect is present in both cases, but the selection effect is only present when leaders are replaced.

${ }^{27}$ If the introduction of elections (with CCP nomination) compelled the CCP to select the candidates that the villagers prefer, then finding no additional effect of open nominations would not provide us with any additional insights into whether better selection played a role.

${ }^{28}$ In principle, another mechanism that can cause elections to increase accountability is candidate competition. The median voter literature suggests that candidate competition should favor candidates that run on platforms that are preferred by a majority of voters. See Black (1948) and Downs (1957) for the classical exposition of this theory and Persson and Tabellini (2000) for a modern textbook treatment. This is not very relevant to our context since median voter models require candidates to be able to campaign on their platforms and to commit to the promises made during the campaign, and there is little campaigning our context. In many cases, elections were set up with only a few days' notice (Unger, 2002: p. 221).
} 
In addition to estimating the effect of introducing elections, our baseline specification also estimates the effect of whether an election is competitive and whether open nominations are used to select the candidates. Since our data show that none of these policies were ever reversed after their introduction, we control for them with dummy variables indicating "post" the year of introduction. The baseline estimation can be characterized by the following equation:

$$
Y_{v p t}=\beta \text { Election }_{v p t}+\theta \text { Competitive }_{v p t}+\lambda \text { OpenNom }_{v p t}+\gamma_{p t}+\delta_{v}+\rho_{t}+\varepsilon_{v p t} .
$$

$Y_{v p t}$ is the policy outcome of village $v$ in province $p$ during calendar year $t$. It is a function of: whether the first election, first competitive election and the first open nomination has taken place; province-year trends, $\gamma_{p t}$; village fixed effects, $\delta_{v}$; and calendar year fixed effects, $\rho_{t}$. All standard errors are clustered at the village level. The main coefficient of interest is $\beta$. It will be statistically different from zero if elections had an effect on a particular policy outcome.

Our empirical strategy assumes that the timing of the introduction of elections is uncorrelated with other factors which may influence the outcomes of interest in the same way as a shift in leader accountability towards villagers. Given the large set of outcomes we examine, we find it unlikely that our estimates are confounded in this way. Nevertheless, to be cautious, we present a large number of robustness checks after we present the main results.

\section{Data}

Our study uses village-level data from a panel of 217 villages for the years 1980-2005. These data are the result of merging two surveys. The first one is the National Fixed-Point Survey (NFS), an economic survey collected and maintained by a research centre of the Ministry of Agriculture of China. It is a longitudinal village and household level survey that began in 1987. The villages were chosen to be broadly nationally representative for rural China at the time the survey began. The NFS data were collected annually during 1987-2005, with the exception of 1992 and 1994, when it was not collected for administrative issues. The second survey is a unique retrospective survey on the history of electoral reforms, de facto leader power, and policies that covers the years 1980-2005, conducted by the authors of this paper in the NFS villages. We also obtained information about the social structure (e.g., kinship clans and the presence of lineage groups) of these villages. ${ }^{29}$ The Data Appendix provides further details on both data sources.

Our sample includes data from 25 out of 32 Chinese provinces. The four provinces that are urban municipalities are not in our sample. ${ }^{30}$ We also exclude Tibet, Inner Mongolia and Xinjiang. These are autonomous regions dominated by ethnic minorities and are subject to different political and economic policies. The full sample includes all of NFS's 217 villages from these 25 provinces. However, for household level variables, the NFS only allowed us access to data for 72 of the 217

\footnotetext{
${ }^{29}$ Lineage groups refers to the presence of ancestral worship halls and written family trees, which according to recent work by Tsai (2007), can affect the provision of public goods in rural China.

${ }^{30}$ These are Beijing, Tianjin, Shanghai and Chongqing. Note that the 31 provincial units do not include Hong Kong or Macau.
} 
villages. ${ }^{31}$ This results in our having many fewer observations when we examine household outcomes. The one exception is household income, which the Ministry of Agriculture agreed to tabulate for us for each decile of the within-village household income distribution each year for each village.

Our data have several advantages. First, these are probably the most comprehensive data on village-level reforms and village-level outcomes ever constructed. Our data cover a larger and more nationally representative sample and span a longer time horizon than any other existing data. In addition to recording the history of electoral reforms, we also recorded the timing of the implementation of other major rural reforms and the occurrence of village mergers. ${ }^{32}$ This allows us to control for heterogeneity across villages more comprehensively than past studies, which is particularly important in a study of China during a period of large and widening disparity between regions. Second, the NFS economic data is collected contemporaneously. This avoids measurement error that would arise from using retrospectively recalled data on past details. Third, the panel structure of the survey allows us to control for village fixed effects and province-year trends. Finally, the richness of the data allows us to provide a detailed analysis of the effect of elections across policy types and to assess the mechanisms driving the reduced-form effects.

The main drawback is that the variables included in the NFS change over time to meet the needs of the Ministry of Agriculture. To maximize the accuracy and precision of our study, we focus on variables that are collected consistently for most years. As a consequence, some interesting variables that are only in the survey for very few years (e.g., obligated working days, roads) are not examined. The second drawback is that the NFS, which is mainly an agricultural labor and production survey, did not collect detailed demographic data. Therefore, we cannot examine outcomes such as yearly changes in fertility, or explore the interaction of the effects of elections and changes in the village demographic structure. Finally, because we have only household-level data for 72 villages, our estimates for these outcomes will be less precise.

\subsection{Descriptive Statistics}

Village Demographics Table 1 contains the descriptive statistics for the villages in our dataset. All observations are at the village-year level. Panel A shows the means for the full sample. The main facts that emerge is that our sample is very rural and very few villages are near cities. ${ }^{33}$ Land expropriation by the upper government occurs rarely. Only in $4 \%$ of the village-year observations experience upper-government land expropriation. However, exemptions to the One Child Policy are allowed in half of the sample. In addition to the means shown in Table 1, we find that the average standard deviation of this variable within a province and year is 0.37 , which shows that there is substantial time and regional variation in the enforcement of tehe One Child Policy. This

\footnotetext{
${ }^{31}$ In order to maximize the sample size, we chose the 72 villages with the largest number of households.

${ }^{32}$ For example, our survey records the year that villages implemented the Household Responsibility reforms (mid1980s), which de-collectivized agricultural production, and the Tax and Fee Reforms (early 2000s), which reduced village leaders' ability to tax villagers.

${ }^{33}$ The number of observations vary because some of the measures, such as the size of the dominat clan, are not relevant for all villages.
} 
supports the observation that local governments have some discretion over the implementation of family planning policies. Table 1 also shows that approximately $60 \%$ of funding for village public goods comes from village sources, which is consistent with the belief that one of the main roles of the village government is to raise and target public investment. Most of the arable land (96\%) is allocated to household farming. For the remaining land, a third is typically leased out to village enterprises and a third is managed collectively, which can be used for any purpose. The uses of the residual third of the land held by the village government is not reported by the NSF.

Next, we examine the descriptive statistics for income. For the full sample of 217 villages, the median household earns approximately 10,512 RMB of gross income per year. ${ }^{34}$ The median household income of each village grows at $9.2 \%$ per annum on average, which is similar to the growth rate for the national average during this period.

Panel B shows the descriptive statistics for select variables from the subsample of villages for which we have household-level data. These villages are slightly larger in terms of the number of households and have similar median income and income growth as the full sample of villages. In addition to the descriptive statistics shown in Table 1, the disaggregated income data that we have for this subsample shows that agriculture is very important for the incomes of households in our sample (see Appendix Table A1 panel A).

One of the most important variables from this subsample is the amount of land allocated to each household. The data highlight how little farmland rural Chinese households have. The median household in a village has approximately $5.24 \mathrm{mu}$ on average. ${ }^{35}$ The household subsample also allows us to examine the amount of fees and levies paid by households to the village and county governments, which amounts to 320 RMB per year on average. Unfortunately, the NFS does not separately report fees paid to the village government from fees to the county government. Appendix Table A1 panel A shows a more detailed account of household income and expenditure. Aside from production costs and food and housing consumption, the main expenses are the payment of fees and school tuition. This is consistent with past studies that argue that household fees are a contentious issue within the village (e.g., Luo et al., 2007; Zhang et al., 2004).

Village Government Structure Panel C shows the descriptive statistics for the village government. On average, there are four village committee members (including the VC) and seven party committee members in the village party branch (including the PS). We only have data for VCs that were in office before the first election for sixteen villages. ${ }^{36}$ Within this small subsample, we observe that $60 \%$ of the first elections resulted in a change in the $\mathrm{VC}$, showing that the initial elections resulted in substantial turnover. If we examine all elections (and not just the first), we find that $46 \%$ of elections result in a change of $\mathrm{VC}$, which shows that elections continued to generate leader

\footnotetext{
${ }^{34}$ During most of our study period, $1 \mathrm{RMB}$ was approximately equal to 8 USD. The incomes we report are not adjusted for inflation. In the regression analysis, price changes are largely absorbed in the year fixed effects and province-time trends.

${ }^{35} 1 \mathrm{mu}=1 / 15$ th hectare.

${ }^{36}$ The surveyors collected data on the VCs and PSs for all villages and years after the first election was introduced. For sixteen villages, the surveyors also collected these data for all the years before the first election.
} 
turnover. $^{37}$

In Table 2, we document the power structure of the government by asking whether the $\mathrm{VC}$ or the PS had the unilateral power to make important decisions or if consent from both was necessary to reach a decision. Our survey question is phrased to reflect the de facto rules rather than the de jure rules. ${ }^{38}$

Table 2 shows that there is substantial variation in the allocation of power and that VCs have de facto power. VCs have unilateral powers to appoint managers of village enterprises in $32 \%$ of the sample, to employ village-government employees in $27 \%$ of the sample, to reimburse expenses in $56 \%$ of the sample, to reallocate land in $33 \%$ of the sample and to make large public investments in $18 \%$ of the sample. Adding up the cases in which VCs have unilateral and joint power shows that their consent is needed for important decisions in about $70-90 \%$ of the sample.

The Timing of the First Elections Panel D of Table 1 presents the descriptive statistics on the timing of elections. It shows that the average village had held its first election by 1988, its first competitive election by 1991 and its first election with open nominations by 1997.39 There are fewer observations for the latter two variables because not all villages had introduced these policies by the end of our study period. Note that our regression analysis will include all villages because villages that had not introduced certain policies will simply report those variables as zero.

Next, we examine the timing of the introduction of elections in each village relative to the introduction in the same county and the same province. For county-level introductions, we can rely on our survey, which asked each village to recall when the first elections were held in the same county (excluding the respondent village) ${ }^{40}$ As provinces are large and many villages will not know the first election in its province, we did not include such a question on the survey. Instead, we proxy for the year of the first election within a province with the year of the first election in a province that we observe in our data. Two facts emerge from these statistics. First, most villages introduce elections at the same time as the rest of the county and very soon after the first election in the same province. In addition to the means presented in the table 1 , we find that $66 \%$ of villages introduce elections together with the first village of the same county. The negative sign of the mean differences between average village and county timing is due to the fact that $15 \%$ of our villages were the first

\footnotetext{
${ }^{37}$ Excluding the first election, we have information about 1,043 electoral contests. Among those 477 lead to a change of VC. This contrasts to 229 changes in the PS over the same period. The statistics for leader turnover are not reported in Table 1 .

${ }^{38}$ We used focus groups with village officials and elders to identify the most important policies for villages. We focused on policies that were the most likely to be relevant for all villages across China. For each year, respondents check boxes for whether the signature of the VC, PS or both are needed to implement each policy. Not all policies are relevant to each village and time period. In case of an irrelevant policy, the variable is recorded as missing. Therefore, the sample size varies across outcomes. Note that the land allocation question specifically refers to land that is held by the village government and allocated at the sole discretion of the village government (e.g., jidongdi). This is important because our empirical analysis of the effect of elections on village land allocation only makes sense if the $\mathrm{VC}$ has power over land allocation.

${ }^{39}$ See Appendix Table A2 for a more detailed timing of the introduction of these reforms.

${ }^{40} 13$ villages were unable to recall the year of the first election in their county. Therefore, our sample size for this variables is slightly reduced.
} 
to introduce elections in their county. ${ }^{41}$ Second, the villages in our sample include those that held their first elections before, at the same time as and after the first election held in the same county, which is consistent with our villages being a random sample.

Electoral Procedures There are substantial differences in electoral procedures beyond the number of candidates discussed earlier. Panel D of Table 1 also shows that there is substantial heterogeneity in electoral procedures. Approximately $84 \%$ of elections have anonymous voting, $72 \%$ allow voting by proxy and $65 \%$ use a roving ballot box. Despite the mandate of holding competitive elections, only $79 \%$ of elections follow this requirement. These facts are consistent with previous observations that many elections are procedurally unsound. ${ }^{42}$

In addition to the statistics shown in the table, we also investigate the frequency of elections. Although $80 \%$ of elections occurred exactly three years after the previous one (as stipulated by law), over $10 \%$ of elections follow the previous one within one or two years. Interestingly, all of these high-frequency elections occurred immediately after the initial introduction of elections. Moreover, they typically occurred after elections that were not competitive. The fact that non-competitive elections were systematically followed by additional elections before the term's end is consistent with the qualitative accounts of dissatisfied villagers demanding and obtaining recalls provided by O'Brien and $\mathrm{Li}$ (2006) and the belief that the introduction of elections could shift accountability of village government towards villagers even when the elections were very imperfect.

\section{Main Results}

This section presents our main empirical results. First, we check that elected leaders have power over policy decisions by estimating the effects of the introduction of elections on the de facto power of leaders. Second, we present the estimated effects of elections on Type I policies to infer whether elections increased the VCs accountability towards villagers. Then we examine the effects of elections on Type III (e.g., placebo) policies to check that elections do not affect policies that the VCs have little discretion over. Finally, we examine the effect on Type II policies to investigate whether villagers are better than the upper government in monitoring the $\mathrm{VC}$.

\subsection{The Effect on Leader Powers}

First, we examine the effects of elections on de facto leader powers. The estimates for the baseline equation (1) are shown in Table 3. The estimates in rows (1)-(5) show that elections increase the unilateral power of the $\mathrm{VC}$ for each of the village powers in our survey. With the exception of the

\footnotetext{
${ }^{41}$ In addition to the statistics reported in the table, we find that over $60 \%$ of villages within a province introduced elections within three years of the first election in that province.

${ }^{42}$ Several past studies have observed that the quality of the electoral procedures is highly uneven (Brandt et al., 2004; Pang and Rozelle, 2006; Birney, 2007). A roving ballot can decrease the ability of citizens to monitor the ballot box and facilitate ballot stuffing. Similarly, the lack of anonymous ballots could increase the pressure on villagers to vote for a particular candidate. Allowing villagers to vote in proxy of family members that are away can be important in the context of villages where many workers work away from the village part of the year.
} 
power to employ village staff, they are significant at the $10 \%, 5 \%$ and $1 \%$ levels. This is paralleled by a decrease in the unilateral powers of the PS shown in rows (11)-(15), which are also statistically significant at the $5 \%$ and $1 \%$ levels with the exception of the power to employ staff. Elections have no effect on the incidence of the PSs and VCs holding powers jointly. These results are important because they show that the newly elected leaders had powers to implement policies. Otherwise, it would not make sense to infer a shift in leader accountability from the estimated effect of elections on policy outcomes. Moreover, they are consistent with the belief of the proponents of reform that elections increase the de facto power of the elected official by giving him a democratic mandate.

Interestingly, the subsequent introductions of competitive elections and open nominations do not have additional effects. The estimates are mostly small in magnitude and statistically insignificant. Note that the estimated magnitude for the introduction of the first election is similar if we do not control for the subsequent introductions of competitive elections and open nominations. However, not controlling for this additional heterogeneity causes the election estimates to be less precise. Therefore, we include these controls in all of our specifications. ${ }^{43}$

\subsection{Effect on Upper-Government Policy}

As we discussed earlier, an increase in leader accountability towards villagers (due to the introduction of elections) has different effects across policy types. Specifically, it depends on whether the village government has any discretion over the policy and the congruence between the preferences of the upper government and villagers. Our simple model predicts that if elections increase accountability towards the villagers, then upper-government policies that are unpopular with villagers will shift towards the preferences of villagers if VCs have any discretion over them (i.e., Type I policies). It also predicts that elections should have no effect on policies over which the village government has no discretion (i.e., Type III policies). We examine these predictions in Table 4.

The two Type I polices that we examine are the One Child Policy and upper-government land expropriation (recall the discussion from section 3). Column (1) shows the estimates of the effect of elections on the implementation of One Child Policy exemptions. Elections increase the incidence of relaxations in the One Child Policy by 8.2 percentage-points. Since approximately $50 \%$ of our observations allow the exemption, this represents a $16 \%$ increase in the likelihood of exemptions. The estimate is statistically significant at the $1 \%$ level. Column (2) examines the effects of elections on the probability of village land being expropriated by upper-level governments. As we can see, this probability is reduced by 1.8 percentage-points once elections are introduced. However, the point estimate is only statistically significant at the $15 \%$ level. The lack of precision most likely reflects the fact that there is very little variation in this measure because land expropriation rarely occurs; only $3.6 \%$ of our sample experiences land expropriation by the upper government. This also means that the estimated magnitude implies a large effect and that elections approximately reduce the average incidence of land expropriation by $49 \%$.

\footnotetext{
${ }^{43}$ The estimates without controlling for competitive elections and open nominations are not reported in the paper for the sake of brevity. They are available upon request.
} 
In contrast, we find that elections have no effect on Type III policies that the village government has little discretion over. Columns (3) and (4) show that elections have no effect on the amount of public investment from special aid funds or distance to the nearest high school.

These results are consistent with the predictions of our model when elections increase leader accountability towards villagers. More specifically, the finding that elections reduce unpopular policies means that elections shift Type I policies towards the preferences of villagers. This implies that the introduction of elections indeed increased leader accountability towards villagers. The finding that elections had no effect on Type III policies reinforces our interpretation that the estimated effects on Type I policies are driven by a shift in local leader accountability rather than by other mechanisms.

As with the results on leader powers, we find that the introduction of open nominations and competitive nominations have little additional effect.

\subsection{The Effect on Public Goods Investment and Village Land Allocation}

Next, we analyze the effect of elections on public goods provision and within-village land allocation. These polices correspond to the Type II policies in our model, for which villagers and the upper government share similar preferences but a proper implementation is costly to the village leader. Our model predicts that a shift in accountability towards villagers shifts these policies towards the preferences of the villagers only if villagers are better than the upper government at monitoring and restraining the VC.

Table 5 shows the results on the effect of elections on public investment according to the sources of funding. For the sake of brevity, we do not report the estimates for post-first competitive election and post-first open nomination. Panel A shows the results for total public investment for all public goods. Column (1) shows that elections increase total public investment from all sources by approximately $17.5 \%$. However, it is only significant at the $15 \%$ level. Columns (2)-(7) disaggregate village expenditure in public goods by source of funding. A comparison of the magnitude of the coefficients in column (1) and those in columns (2)-(7) suggest that the aggregate increase is driven by an increase in funding from villagers. However, these estimates are not statistically significant. The imprecision is very likely due to heterogeneity in the demand for public goods.

To address this issue, we predict the demand for public goods with village characteristics. Our data allows us to do this for two public goods: irrigation and schooling. Presumably, villagers living in villages where there is more household farming will demand more irrigation and those who live in villages with more children will have higher demand for schools. In order to examine the effect of elections on irrigation investment, we estimate an equation similar to the baseline equation, except that we add the interaction terms that interact the introduction of elections, competitive elections and open nominations with the average log amount of village land used for household farming. Similarly, to examine the effect on schooling investment, we add interaction terms that interact the three policy variables with the average number of children of ages 7-13 in a village.

Panel B in Table 5 shows the effects on irrigation investment. The estimate for the main effect 
of post-first election in column (1) shows that elections reduce public investment in irrigation for villages with no household farmland. However, the interaction effect between elections and average log household farmland is positive. Both the main and interaction effects are statistically significant at the $1 \%$ level. Taken literally, the estimates show that elections increase public investment in irrigation for villages that have 6.5 or more log mu of land (the sample mean is $7.23 \log \mathrm{mu}$ ). The elasticity of household farm land with respect to the effect of elections on public investment in irrigation is 0.37 .

In Panel C, we examine the effect on public investment in schooling. Column (1) shows that elections have no effect on public investment in schooling for villages with no children. In fact, the sign of the estimate is negative. However, the introduction of elections increases public investment for villages with more children. The interaction term is statistically significant at the $1 \%$ level. Note that all of the coefficients for schooling are scaled by 1,000 for ease of presentation. Therefore, the results show that elections increase public investment in schooling from villagers for the average village, which has approximately 234 school age children, by $0.4 \%(234 \times 0.0154 / 1000)$ more than a village with no children. This is a small effect. However, the result is consistent with the observation that elections increase the provision in public goods for which there is stronger demand from the villagers.

The estimates in Panels B and C provide strong evidence that elections increase appropriate provision of public goods. Furthermore, a comparison of columns (2) to columns (3)-(7) shows that the effects of elections on public investment are entirely driven by increases in funding from villagers. The estimated main effects and interaction effects for investment funded by sources other than from the village government are statistically insignificant and much smaller in magnitude, relative to investment funded by villagers. These results are important because they show that the estimated effects on public goods are driven by changes in policies that the village leader has much discretion over and not by a change that he has little discretion over. This reinforces our interpretation that our results capture a change in village leader accountability.

As a consistency check, we investigate the effect of elections on fees paid by households. Since we find that elections increase the amount of village funding for public goods, we would also expect elections to increase the amount of fees paid by villagers to the village government, which we can only observe together with the fees paid to the county government. Using the subsample of villages for which we have household data, we find that elections indeed increase the total amount of fees paid to the village and county. These results are shown in Appendix Table A3.

Table 6 shows the estimates for the effects of elections on within-village land allocation. We examine the effects on each decile of the within-village distribution of land allocation to investigate whether elections induce redistribution. Columns (1)-(9) show that the estimated coefficients are positive for the entire distribution. However, they are larger in magnitude and more precisely estimated for households near the median. Columns (4)-(6) show that the introduction of elections increases household farmland by approximately $20-28 \%$ for the 40th, 50th and 60th percentile 
households. They are statistically significant at the 10\%, $1 \%$ and $10 \%$ levels. ${ }^{44}$ These results show that elections increased land holding for some households, but there is no obvious evidence of land redistribution across households.

As a consistency check, we investigate whether the increase in household farmland was made possible by a reduction in the land managed directly by the village government. Recall from section 3 that this land is often leased to village enterprises or farmers and is a source of rents for corrupt village officials. The NFS only reports the portion that is leased out to firms or managed collectively, which on average comprises approximately two-thirds of all village government managed land. Because village-government-managed land is typically used for one purpose or another for any given village, we restrict the sample to observations that lease some land out to firms and to observations that manage some land collectively. Columns (10)-(11) show that for these subsamples, elections reduced the amount of land leased to firms by approximately $68 \%$ and the amount of land managed collectively by approximately $71 \%$. The estimates are statistically significant at the $10 \%$ level. These results show that the increase in household land caused by elections was paralleled by a reduction of land that is managed by the government. Note that this is consistent with our earlier finding that the unilateral powers of the VC to reallocate government-held land increased after elections were introduced.

As with all of the earlier results, we find no conclusive evidence that the introduction of open nominations and competitive elections have additional effects. The estimated coefficients are smaller in magnitude and statistically insignificant.

The interpretation of the effects on public goods investment is straightforward. Under the assumption that the upper government shares the preferences of the villagers, our findings are consistent with elections making the village government more accountable to villagers. They also suggest that villagers are better than the upper levels of government at monitoring and restraining village leaders. Interpreting the results on land allocation in the same way requires the assumption that villagers want more land for farming at the expense of reducing the amount of land controlled by the village government. This could occur, for example, if the revenues generated from the government-controlled land were not equitably distributed amongst villagers so that a large portion of villagers preferred to control the land directly. ${ }^{45}$

\footnotetext{
${ }^{44}$ For land allocation and all other outcomes that we examine by quantile, we estimate the distribution for each year. Therefore, a given household that is at the 10th percentile in year $X$, might not be on the 10th percentile in year $Y$. For robustness, we check that our results are similar if we use a time-invariant definition. Since the results are very similar (because there is little change in the relative positions of households on the village distribution of land or income), we only report the time-varying definition in the paper. The other results are available upon request.

${ }^{45}$ We examine the effects of elections on household incomes by source and find suggestive evidence that elections reduce household income from village enterprises (e.g., dividends) and income from wages, which are often earned by working for village enterprises. Richer households experienced larger reductions, which suggests that they benefited more from the enterprises occupying government-controlled land. However, the estimates are very imprecise due to the fact that we only have data on income by source for 72 villages. See Appendix Table A4.

In addition to the main results, our model also makes the auxiliary prediction that an increase in accountability will increase the provision of excludable goods only for as many households as the number of votes the VC requires for remaining in office. These theoretical results are available upon request. Since farmland is an excludable good, the finding that elections only increase land allocation for some households within the village is consistent with this auxiliary prediction.
} 


\section{Robustness}

Causal interpretation of the baseline estimates assumes that the timing of the introduction of elections in villages (within provinces) was not correlated with other factors that could influence our outcomes of interest. Given the large and diverse set of outcomes that we examine, we find it unlikely that an omitted factor could affect all of these outcomes, including the placebos, in exactly the same way as an increase in local leader accountability. Nevertheless, to be cautious, we discuss and address potential threats in this section. First, we check that the timing of the effect of elections on the outcomes corresponds closely to the timing of the first election, rather than spurious changes that may have occurred some years before or after the election. Second, we address the possibility that the timing of the introduction of elections was endogenous to other factors that can influence our outcomes of interest. Third, we address the related concern that villages that introduced elections before the national OLVC law differed from villages that introduced elections afterwards. Finally, we discuss alternative explanations for our findings.

\subsection{Year-by-Year Estimates}

We estimate the effect of the introduction of elections for each year before and after the first election to check that changes in the outcome of interest occur when elections are first introduced, or closely afterwards. We estimate an equation that is similar to the baseline except that we introduce dummy variables for the number of years since the first election. The outcomes we examine are limited to those that have sufficient variation within each year. We only extend the pre-election analysis to four years prior to the first election to avoid losing too many villages that introduced elections early. Similarly, we examine up to six years after the first election to avoid losing villages that introduced elections towards the end of our sample.

Figure 1 plots the estimated coefficients for the correlation between the dummy variable for each year before and after the first election and the power of the VC and PS to unilaterally appoint village enterprise managers. The plotted coefficients show that there is little change in the three years prior to the first election. However, the likelihood that VCs would have unilateral power instead of the party secretary immediately increases after the first election. The same pattern exists for all other decision power measures (see Appendix table A5).

Figure 2 shows the estimated effects for whether One Child Policy exemptions were granted in a village. As with village leader powers, we see no effect in the years leading up to the introduction of the first election but a jump to a positive correlation in the years afterwards.

We repeat this exercise for land holdings of the median household. Because this variable is only reported from 1987 onwards, we can only extend the analysis to two years prior to the first election without losing too many villages from the estimating sample. The estimated coefficients are

plotted in Figure 3. Figure 3 shows no change between one and two years before the introduction of elections. After the introduction, villages gradually allocate more land to the median household.

The estimated coefficients and standard errors for these policy outcomes are shown in Appendix 
table A5.

These results illustrate that the effects of elections occur at the time of the first election or shortly thereafter, which partly alleviates the concern that our main pre-post comparison captures spurious changes. Note that the estimates provide no evidence of pre-trends. ${ }^{46}$

\subsection{Endogeneity of Election Timing}

Our main concern is that our estimates are biased by the fact that the upper government delayed elections for villages that had a history of resisting central policies. If the upper government successfully delays introducing elections in villages that will deviate the most from central policies, then our estimates of the effect of elections on reducing the enforcement of upper-government policies are clearly attenuated. ${ }^{47}$

Delaying the introduction of elections for such villages is unlikely to bias our estimates of the effect of elections on public goods provision since the upper government has little stake in this outcome. However, our strategy could over-estimate the effect of elections on within-village household land allocation. One of the stated motivations of introducing elections was to reduce corruption by allowing citizen monitoring. Since one of the most common ways for village leaders to earn rents is from government-held land, one may worry that upper governments introduced elections earlier in villages that experienced more corruption. Thus, our estimated effects of elections on land allocation may overstate the true effects. In this section, we address this and many other concerns.

It is convenient to categorize the potential bias as two types: bias arising from heterogeneity across villages within counties and bias arising from heterogeneity across counties. We can address the first type of bias by instrumenting for the timing of the first election in each village with the timing of the first election in the same county. For example, if the upper government introduced elections in villages where the demand for additional farmland was greater, then instrumenting for village timing with county timing can remove the endogeneity from differences across villages within counties. The causal interpretation of this instrumental variables strategy also assumes that the introduction of elections at the county level is not systematically correlated with village level factors of the villages in our sample that affect the outcomes of interest. This seems highly

\footnotetext{
${ }^{46}$ Moreover, the discrete change in the coefficients after elections were introduced suggests that our main specification, which estimates the average effect of elections across all the years after their introduction, will be appropriate for capturing the effect of elections. For the estimates on household land allocation, the gradual and approximately linear change in the coefficients after the introduction of elections suggests that estimating the effect of the number of years since the first election may be more appropriate than our main specification for capturing the cumulative effects of elections after they were introduced. When we estimate this alternative specification, we obtain statistically significant estimates that imply the same average effects as our main results. Therefore, for the sake of brevity and consistency, we only report the results from our main specification in the paper. The alternative estimates are available upon request.

${ }^{47}$ If problematic villages do not enforce central policies even before elections, then it is possible that they have a smaller margin for change after elections are introduced. This could cause our estimate to overstate the true effects of elections on reducing the enforcement of unpopular central policies. To address this, we control for the average incidence of One Child Policy exemptions and the upper government expropriation of land for each village, each interacted with the full set of year dummy variables, in our baseline regression. Our results are unchanged when the interactions controls are included. Therefore, we conclude that they are not biased upwards by pre-election non-compliance. The estimates are presented later in the paper.
} 
unlikely since our sample villages are randomly chosen from the counties they are in and each county typically contains over 200 villages. Even if counties decided to introduce elections based on the unobserved characteristics of certain villages, it is highly unlikely that they systematically made this decision based on the villages in our sample. The first stage and 2SLS estimates are shown in Table $7 .{ }^{48}$ The first stage estimates are very strong and significant. The 2SLS estimates have the same sign as our baseline estimates but are larger in magnitude. They are almost all statistically significant. Therefore, we conclude that our baseline estimates are not biased upwards (in magnitude) by heterogeneity within counties.

It is more difficult to address the omitted variables bias caused by heterogeneity across counties. We do not have a convincing source of plausibly exogenous variation in timing at the county level that we can use as an excludable instrument. Therefore, we address this difficulty by directly controlling for potentially confounding factors. We identify these factors as the correlates of the year of the introduction of elections across villages (within provinces). Our choice of correlates is motivated by qualitative studies on the motives for elections, such as poor enforcement of central policies, and the factors that are most likely to cause discontent amongst villagers. ${ }^{49}$ We experimented with a large number of different specifications and find no statistically significant correlates for election timing. This is consistent with the claim that election timing was, for the most part, quasi-random within provinces. However, one may be concerned that the timing of elections is correlated with unobservable factors that influence our outcomes of interest or that the estimated correlates using a 217-village cross section can be misleading due to a lack of power and vulnerability to collinearity. Therefore, to be cautious, we control for these factors and all of the other factors which could be potentially confounding in Tables 8 and 9 .

The robustness checks in Table 8 focus on factors that are most likely to be directly related to latent demand for the policy outcomes that we examine. For each variable, we calculate a timeinvariant village average to address the concern that the time varying measures may be outcomes of elections. We then interact the village averages of each characteristic with the full set of time dummies to allow the effects to vary fully flexibly over time. ${ }^{50}$ The robustness controls include the

\footnotetext{
${ }^{48}$ Note that we only have enough variation for the 2 SLS estimates with our full sample variables. We use two specifications, one where we only instrument for the first elections, and a second where we instrument for the first election and first open nominations. Our survey also asked each village to recall the first open nomination by any village in the same county. Table 7 shows that the two specifications yield very similar results.

${ }^{49}$ We examine the correlates of timing in the cross section. To make our estimates comparable to the baseline, we demean the data by province-year trends and then aggregate the data to the village level. The outcome variable of interest is the year of the first election in the village. The correlates we examined were the village averages of population, population growth rate, fertility, the incidence of upper-government land expropriation, village land allocated for household farming, a dummy for whether a village is near a large city, household income and income growth for the 10th, 50th and 90th percentile households, income inequality and the growth rate of income inequality. We also examine the relationship between election timing and the presence of a lineage group and the size of the largest kinship clan. On the smaller 72 village household data subsample, we replace the income measures with analogous household land measures. Due to space constraints, we do not present these correlates in the paper. They are available upon request. Note that many demographic variables, such as fertility, are reported by the NFS in only a few years. Therefore, we cannot examine them as outcomes in the main analysis. However, for these robustness exercises, we are able to use them by calculating a village average over time and interacting them with year fixed effects.

${ }^{50}$ Note that we can alternatively use the village averages calculated from the years prior to the first election in each
} 
interaction terms of the full set of year fixed effects with the village averages of: median household land allocation, household land inequality (measured as the land holding of the 90th percentile household divided by the land holding of the median household), total village land used for household farming, land leased to firms, the incidence of upper-government land expropriation, whether the village is part of the suburbs of a city, household fees paid to the county and village level governments, fertility rates, the percentage of laborers, the incidence of One Child Policy exemptions, median household income, household income inequality and household income growth. Some of these additional controls are only available for the 72-village sample with household-level data. As a result, we cannot estimate the effect of elections on public investments with these robustness controls because public investments occur very infrequently and we do not have enough variation in the data.

We present the baseline estimates for each of our outcomes for comparison purposes in column (1) and then add the controls individually in columns (2)-(10). In column (15), we control for all of these factors in one regression. In Panels $\mathrm{C}, \mathrm{D}$ and $\mathrm{E}$, the estimates change in magnitude when the sample changes from the full 217 villages to the 72 villages with household data. We find a similar change in magnitude when we estimate the baseline equation using the restricted sample without any additional robustness controls. ${ }^{51}$ The additional controls have almost no effect on the estimated magnitudes of the coefficients. ${ }^{52}$ Therefore, we conclude that our main estimates are robust to the factors that are most likely to influence the policy outcomes we examine.

In Table 9, we examine additional factors that may influence the adoption or effectiveness of elections. As before, we present the baseline estimates for comparison in column (1). We examine the influence of election procedures discussed in section 5: the presence of a roving ballot box, anonymous ballots and proxy ballots, which could all corrupt the election process. We control for these electoral procedures in column (2). The estimates are very similar to the baseline for all outcomes.

Another factor that can influence the effect of elections is the share of the largest clan. When elections were introduced, many officials feared that a large extended family would dominate elections and then use its power in the elected office to implement policies which may not be beneficial for the rest of the villagers. Alternatively, having a large dominant clan could facilitate coordination in making decisions for policies such as public goods. In column (3), we control for the interaction of the fraction of the village that comprises the largest clan, a time-invariant variable, with year fixed effects. Our estimates are robust to these controls. ${ }^{53}$

Next, we consider Tsai (2007)'s argument that strong informal institutions are major determi-

village. This does not affect our results. Therefore, they are not shown for the sake of brevity, but they are available upon request.

${ }^{51}$ These are not reported for the sake of brevity. They are available upon request.

${ }^{52}$ Note that we also checked that our results (in particular, the estimate for public investment in schooling) are robust to the inclusion of the average number of children interacted with year fixed effects. These regressions are not included for the sake of brevity. They are available upon request.

${ }^{53}$ We also used alternative measures, such as the share of the largest two clans and a dummy for whether the largest clan was more than half of the village population, as controls. The estimates are very similar to the baseline. They are not reported for the sake of brevity and are available upon request. 
nants of policy outcomes, which could weaken the effect of elections. We follow her work in using the presence of a lineage group, which is measured as the presence of a household with a family tree or an ancestral temple, to proxy for informal institutions (e.g., social capital). In column (4), we control for the interactions of each of these variables with year fixed effects. The estimates are very similar to the baseline.

In column (5), we control for the introduction of the Tax and Fee Reform, which restricted the collection of fees by village governments. Since such fees were the main source of funding for village public goods, especially in poor villages, this would greatly curb the village government's ability to provide public goods. ${ }^{54}$ We investigate whether our baseline results, particularly those on public goods investment, are robust to controlling for the introduction of this reform. The estimates in column (5) show that our main results are robust to controlling for this reform.

In column (6), we control for whether a village had experienced a merger with another village. Approximately $19 \%$ of our sample ever experienced a merger at some point. ${ }^{55}$ To address this, we asked villages in our survey to report the years they experienced mergers. We created a dummy variable indicating whether a village ever experienced a merger (since 1952), then control for the interaction of this dummy variable with year fixed effects. As we can see from column (6), the estimated effect of elections is very similar in magnitude to the baseline. ${ }^{56}$

Finally, in column (7), we control for all of the factors described above simultaneously. This rigorous specification produces estimates that are very similar in magnitude to the baseline. Therefore, we conclude that our main results are robust to controlling for a large host of additional factors.

\subsection{Early Movers}

Another concern related to heterogeneity and election timing is the possibility that villages that held their first elections before the OLVC in 1987 were different from villages that held their first elections afterwards. For example, provincial governments may have first introduced elections in villages that were see to benefit from elections but delay introducing elections in other villages until they were required to by the national law. In that case, our estimates will misrepresent the true average effect of elections. To address this, we re-estimate our baseline regression on a sample restricted to villages that held their first election after 1987. Table 10 shows a comparison of the

\footnotetext{
${ }^{54}$ Our survey asked each village to report the introduction of the Tax and Fee Reform (and the introduction of the Household Responsibility System). The data show that the timing of the introduction of these policies is uncorrelated with the timing of the introduction of elections. Hence, it is quite unlikely that our estimates are confounded by these other policies.

${ }^{55}$ This could be problematic for our data because our retrospective survey in 2006 allowed villages to provide the electoral history of only one village. If a village was merged with another in the past, it is not clear which village is being represented in the historical survey. The NFS data faces similar problems. A second potential problem comes from the possibility that villages that have been merged with other villages can have very different electoral experiences. For one, merged villages may have more heterogeneity in their constituents, which could affect electoral outcomes. Alternatively, one may worry that villages which experienced mergers were either particularly problematic or prosperous villages that also introduced elections systematically earlier or later.

${ }^{56}$ The estimates are also similar in magnitude to the baseline if we drop villages that have ever experienced a merger, but they are less precise. We do not show these results for the sake of brevity. They are available upon request.
} 
results on the restricted sample with our baseline estimates. They are very similar. ${ }^{57}$

\subsection{Alternative Interpretations}

Finally, one may be concerned that our outcomes may be driven by changes in upper-government policies that occurred with the introduction of elections rather than by a shift in leader accountability caused by the introduction of elections. For example, the upper government may induce villages to introduce elections by favoring them with advantageous policies. If it relaxed the One Child Policy or rescinded land expropriation requests at the same time that it introduced elections in villages, then our results would partly reflect upper-government favoritism. This is mostly a concern for our estimates of the effect of elections on policies that the upper government has control over (e.g., upper-government land expropriation, implementation of the One Child Policy, and the part of public goods funded by the upper government).

We show several pieces of evidence against this alternative explanation. First, if the upper government systematically favored certain villages with advantageous policies after the introduction of elections, then one would expect this favoritism to also appear in policies under the sole control of the upper government. Such policies are arguably easier for the upper government to change as it can do so unilaterally. This is inconsistent with our results, which show that elections do not affect two policies that villagers clearly favor and are under the sole discretion of the upper government: special aid for below poverty line households and the distance to secondary schools. Second, our results on public goods provision show that the increase in public investment caused by elections is entirely driven by funding from villagers. There is no effect on funding from other sources. These results provide additional evidence against the alternative interpretation that our strategy captures the effect of upper-government favoritism rather than a shift in leader accountability.

\section{Conclusion}

In this study, we collect a unique dataset on the political history of rural Chinese villages that we match to economic data that the Chinese government collected contemporaneously. Our data covers most of rural China and most of the post-1976 reform era. We develop a simple framework for understanding the effects of a change in local leader accountability on village policies. Our findings show that elections changed policy outcomes in a pattern that is entirely consistent with an increase in village leader accountability towards villagers. Therefore, they provide strong evidence that a local shift towards democracy can effectively increase local leader accountability towards his constituents, even if the overall regime is authoritarian.

The results provide several additional insights. First, the finding that the introduction of open nominations has no clear incremental effect suggests that the increase in accountability is more likely

\footnotetext{
${ }^{57}$ In addition, we also test whether our results are driven by underlying trends by randomly generating the year of the first election and estimating the effects of this random election. We find that the randomly generated elections have no effect. These results are not reported in the paper for the sake of brevity. They are available upon request.
} 
to be driven by stronger incentives rather than by better selection of leaders. Second, the finding that elections affect policy outcomes, even for policies that villagers and the upper government have similar preferences for, suggests that the villagers have an advantage in monitoring village leaders.

For policy makers, our results indicate that making local officials more accountable to the population at large can have noticeable effects on policy even if such changes are marginal, imperfectly implemented and occur in a broader context of authoritarianism. This is important for the debate on political institutional change because it suggests that wholesale reforms at all levels of a regime might not be necessary to obtain noticeable benefits for the population at large. Furthermore, the findings show that local democracy poses a trade-off for the authoritarian central regime. On the one hand, local democracy reduces the enforcement of certain unpopular central policies. On the other hand, elected village leaders seem to be able to better provide for the needs of villagers on average. This could be beneficial for the regime in the long run by decreasing the probability of political unrest.

The Chinese context and the data that we have collected provides a promising ground for future research on the effect of local governance changes within an authoritarian regime. Our future research includes studies of the interactions between formal institutions, such as elections and informal institutions, such as social capital, which can help us understand the pre-conditions for successful institutional change. We also plan to explore the hypothesis that China's authoritarian central government is using local elections to obtain information from a large, heterogenous and rapidly changing country by studying the effects of local elections on the characteristics of CCP appointees over time. Similarly, our next survey will also collect data on the occupations and incomes of elected and appointed leaders and their family before and after they are in office to better understand the incentives of these politicians and bureaucrats.

\section{References}

Acemoglu, Daron and James Robinson, "Persistence of power, elites, and institutions," American Economic Review, 2008, 98 (1), 267-293.

_, Simon Johnson, and James Robinson, "The Colonial Origins of Comparative Development: An Empirical Investigation," American Economic Review, 2001, 91 (5), 1369-1401.

Alesina, Alberto and Guido Tabellini, "Bureaucrats or politicians? Part I: A Single Policy Task," American Economic Review, 2007, 97 (1), 169-179.

Banerjee, Abhijit V., Selvan Kumar, Rohini Pande, and Felix Su, "Do Informed Voters Make Better Choices? Experimental Evidence from Urban India," Working Paper, MIT Working Paper 2010.

Bardhan, Pranab and Dilip Mookherjee, "Decentralization, Corruption and Government Accountability: An Overview," in Susan Rose-Ackerman, ed., International Handbook of the Economics of Corruption, Northampton, MA: Edward Elgar Co, 2006. 
Barro, Robert, "The Control of Politicians: An Economic Model," Public Choice, 1973, 14, 19-42.

Barro, Robert J., "Democracy and Growth," Journal of Economic Growth, 1996, 1 (1), 1-27.

Bernstein, Thomas P. and Xiaobo Lu, Taxation without Representation in Contemporary Rural China, New York, NY: Cambridge University Press, 2003.

Besley, Timothy, Principled Agents: Motivation and Incentives in Politics, Oxford: Oxford University Press, 2006.

_ and Anne Case, "Does Electoral Accountability Affect Economic Policy Choices? Evidence from Gubernatorial Term Limits," Quarterly Journal of Economics, 1995, 110 (3), 769-798.

- and Robin Burgess, "The Political Economy of Government Responsiveness: Theory and Evidence from India," Quarterly Journal of Economics, 2002, 117 (4), 1415-1451.

- and Stephen Coate, "Elected Versus Appointed Regulators: Theory and Evidence," Journal of the European Economic Association, 2003, 1 (5), 1176-1206. K2 by H1.

Birney, Mayling, "Can local elections contribute to democratic progress in authoritarian regimes?" PhD dissertation, Yale University 2007.

Björkman, Martina and Jakob Svensson, "Power to the People: Evidence from a Randomized Field Experiment on Community-Based Monitoring in Uganda," Quarterly Journal of Economics, 2009 .

Black, Duncan, "On the rationale of group decision-making," Journal of Political Economy, 1948, 56 (1), $133 Đ 146$.

Bobonis, Gustavo, Luis R. Camara Fuentes, and Rainer Schwabe, "Does Exposing Corrupt Politicians Reduce Corruption?," Working Paper, University of Toronto 2010.

Brandt, Loren and Matthew A. Turner, "The usefulness of imperfect elections: The case of village elections in rural China," Economics \& Politics, 2007, 19 (3), 453-480.

_, Scott Rozelle, and Matthew A. Turner, "Local government behavior and property right formation in rural China," Journal of Institutional and Theoretical Economics, 2004.

Cai, Hongbin, "A Theory of Joint Asset Ownership," RAND Journal of Economics, 2003, 34 (1), pp. $63-77$.

Chattopadhyay, Raghabendra and Esther Duflo, "Women as Policy Makers: Evidence from a Randomized Policy Experiment in India," Econometrica, 2004, 72 (5), 1409-1443.

Che, Jiahua and Yingyi Qian, "Insecure Property Rights and Government Ownership of Firms," Quarterly Journal of Economics, 1998, 113 (2), pp. 467-496. 
DalBó, Ernesto and Martin Rossi, "Term Length and Political Performance," NBER Working Paper 14511, 2008.

de Janvry, Alain, Frederico Finan, and Elisabeth Sadoulet, "Local Electoral Incentives and Decentralized Program Performance," Working Paper 16635, NBER 2010.

Downs, Anthony, "An Economic Theory of Political Action in a Democracy," Journal of Political Economy, 1957, 65 (2), pp. 135-150.

Ferraz, Claudio and Frederico Finan, "Exposing Corrupt Politicians: The Effects of Brazil's Publicly Released Audits on Electoral Outcomes," Quarterly Journal of Economics, 2008, 123 (2), 703-745.

_ and _, "Electoral Accountability and Corruption: Evidence from the Audits of Local Governments," American Economic Review, 2011, Forthcoming.

Foster, Andrew D. and Mark R. Rosenzweig, "Democratization and the Distribution of Local Public Goods in a Poor Rural Economy," Brown University Working Paper, 2004, pp. 1-51.

Gan, Li, Lixin Colin Xu, and Yang Yao, "Local Elections and Consumption Insurance: Evidence from Chinese Villages," World Bank Policy Research Working Paper 4205, 2007, pp. 1-28.

Gandhi, Jennifer and Ellen Lust-Okar, "Elections Under Authoritarianism," Annual Review of Political Science, 2009, 12 (1), 403-422.

Guo, Xiaolin, "Land expropriation and rural conflicts in China," China Quarterly, 2001, (166), $422-439$.

Guo, Zhenglin and Thomas Bernstein, "The impact of elections on the village structure of power: the relations between the village committees and the party branches," Journal of Contemporary China, 2004, 13 (39), 257-275.

Hall, Robert and Charles Jones, "Why Do Some Countries Produce So Much More Output Per Worker Than Others?," Quarterly Journal of Economics, 1999, 114 (1), 83-116.

Jacoby, Hanan G., Guo Li, and Scott Rozelle, "Hazards of Expropriation: Tenure Insecurity and Investment in Rural China," American Economic Review, 2001, 93 (5), 1420-1447.

Kelliher, Daniel, "The Chinese debate over village self-government," The China Journal, 1997, pp. 63-86.

Kennedy, John J., Scott Rozelle, and Yaojiang Shi, "Elected leaders and collective land: Farmers' evaluation of village leaders' performance in rural China," Journal of Chinese Political Science, 2004.

Landry, Pierre, Deborah Davis, and Shiru Wang, "Elections in Rural China: Competition Without Parties," Comparative Political Studies, 2010, 43 (6), 763-790. 
Li, Han, "The Single Party as Source of Legitimacy: Theory and Evidence on Political Mobilization," Working Paper, University of Science and Technology 2009.

Luo, Renfu, Linxiu Zhang, Jikun Huang, and Scott Rozelle, "Elections, Fiscal Reform and Public Goods Provision in Rural China," Working Paper, Freeman Spogli Institute for International Studies, Stanford University 2007.

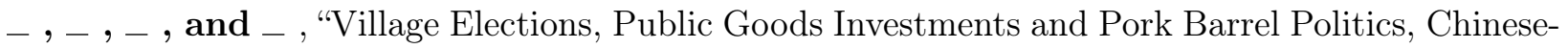
style," Journal of Development Studies, 2010, 46 (4), 662-684.

Martinez-Bravo, Monica, "Appointed Officials and Consolidation of New Democracies: Evidence from Indonesia," MIT Working Paper, 2010, pp. 1-66.

Maskin, Eric and Jean Tirole, "The politician and the judge: Accountability in government," American Economic Review, 2004.

Mauro, Paulo, "Corruption and growth," Quarterly Journal of Economics, 1995.

Meng, Xin, Nancy Qian, and Pierre Yared, "The Institutional Causes of China's Great Famine, 1959-61," NBER Working Paper 16361, 2010.

Mobarak, Ahmed Mushfiq, "Democracy, Volatility, and Economic Development," The Review of Economics and Statistics, 2005, 87 (2), 348-361.

Mu, Ren and Xiaobo Zhang, "The Role of Elected and Appointed Village Leaders in the Allocation of Public Resources: Evidence from a Low-Income Region in China," Working Paper, IFPRI Working Paper.

Mulligan, Casey B., Ricard Gil, and Xavier Sala i Martin, "Do Democracies Have Different Public Policies than Nondemocracies?," Journal of Economic Perspectives, 2004, 18 (1), 51-74.

O'Brien, Kevin and Lianjiang Li, Rightful Resistance in Rural China, New York, NY: Cambridge University Press, 2006.

O'Brien, Kevin J., "Implementing Political Reform in China's Villages," Australian Journal of Chinese Affairs, 1994, (32), 33 - 59.

- and Lianjiang Li, "The Struggle over Village Elections," in Merle Goldman and Roderick MacFarquhar, eds., The paradox of China's post-Mao reforms, Cambridge, MA: Harvard University Press, 1999.

Oi, Jean and Scott Rozelle, "Elections and power: The locus of decision-making in Chinese villages," The China Quarterly, 2000, 162, 513-539.

Olken, Ben, "Monitoring Corruption: Evidence from a Field Experiment in Indonesia," Journal of Political Economy, 2007, 115 (2), 1-50. 
Pande, Rohini, "Can Mandated Political Representation Provide Disadvantaged Minorities Policy Influence? Theory and Evidence from India," American Economic Review, 2003, 93 (4), 11321151.

Pang, Xiaopeng and Scott Rozelle, "A Vote of Confidence? Voting Protocol and Participation in China's Village Elections," Freeman Spogli Institute for International Studies, Stanford University, 2006.

Persson, Torsten and Guido Tabellini, Political Economics- Explaining Economic Policy, Cambridge, MA: MIT Press, 2000.

_ and _, "Constitutions and economic policy," Journal of Economic Perspectives, 2004, 18 (1), 75-98.

Rozelle, Scott and Guo Li, "Village leaders and land-rights formation in China," American Economic Review, 1998, 88 (2), 433-438.

- and Richard Boisvert, "Quantifying Chinese village leaders' multiple objectives," Journal of Comparative Economics, 1994, 18 (1), 25-45.

Shen, Yan and Yang Yao, "Does grassroots democracy reduce income inequality in China?," Journal of Public Economics, 2008, pp. 1-17.

Tsai, Lily L., Accountability without Democracy: Solidary Groups and Public Goods Provision in Rural China, New York, NY: Cambridge University Press, 2007.

Unger, Jonathan, The transformation of rural China Asia and the Pacific, Cambridge, MA: M.E. Sharpe, 2002.

Whiting, Susan, "Contract Incentives and Market Discipline in China's Rural Industrial Sector," in John McMillan and Barry Naughton, eds., Reforming Asian Socialism, The Growth of Market Institutions, Ann Arbor: University of Michigan Press, 1996.

Zhang, Xiaobo, Shenggen Fan, Linxiu Zhang, and Jikun Huang, "Local governance and public goods provision in rural China," Journal of Public Economics, 2004, 88, 2857-2871.

\section{Appendix}

\section{Model}

Our framework applies the insights from the political agency literature to the context of rural China. The introduction of elections shifts the situation of village leaders from being exclusively accountable to upper levels of government to being accountable to both villagers and upper levels 
of government. We therefore need a framework that can capture three levels of players: the village government, the upper levels of government and villagers. ${ }^{58}$

Consider a model with a continuum of size 1 of villagers $(\mathrm{V})$, one village leader (VC) and an upper-government superior $(\mathrm{S})$, which can be any official at the county level or above. The VC decides on two types of policies. The first type includes policies that $\mathrm{V}$ and $\mathrm{S}$ disagree over. We call these policies Type I policies and denote the VC's decisions on this type of policies $m \in[\underline{m}, \bar{m}]$. The second type of policies includes all policy dimensions that $\mathrm{V}$ and $\mathrm{S}$ agree on but implementing them leads to a reduction of the VC's utility. ${ }^{59}$ We call these policies Type II policies, and we denote the VC's decisions by $a \in[\underline{a}, \bar{a}] .{ }^{60}$

We assume that the preferences of villager $i$ are additively separable in these two sets of policies and given by $U_{i}^{V}=m+a+\varepsilon$, where $\varepsilon$ captures other elements that affect V's utility. We assume that $\varepsilon \sim N\left(0, \sigma_{\varepsilon}^{2}\right)$. Aggregate utility in the village is therefore given by

$$
U^{V}=\int U_{i}^{V} d i=m+a+\varepsilon
$$

The S has a dual mandate: keep villagers content and comply with central government policies. We therefore have

$$
U^{S}=U^{V}-c(m)
$$

where $c(\cdot)$ is an increasing, convex and twice differentiable function. $c(m)$ captures the cost that $\mathrm{S}$ bears if there is a lax implementation of central government policies. This cost includes the reprimands from superiors and the negative career consequences on bureaucrats that are seen as failing to implement central directives. Because the upper government is responsible for many villages, each of which has its own particular preferences and experiences some unique shocks, we assume that the upper government cannot perfectly observe V's utility and instead only observes an informative signal. Denote this signal by $s=U^{V}+\theta$, where $\theta \sim N\left(0, \sigma_{\theta}^{2}\right)$ and is independently distributed from $\varepsilon$. When $\mathrm{S}$ takes the decision to retain or replace the $\mathrm{VC}$, it can only use this noisy measure

$$
\tilde{U}^{S}=s-c(m) .
$$

We assume that the $\mathrm{VC}$ values being in office and suffers a loss, $l(a)$, associated with the implementation of Type II policies, where $l(\cdot)$ is an increasing, convex and twice differentiable function. This loss captures both economic or social rents lost, or effort exerted in such policy

\footnotetext{
${ }^{58}$ Our model focuses on the incentive channel because it is the most relevant for our context and for simplicity. Adding selection does not change the main results. For the sake of brevity, this extension is not shown in the paper. It is available upon request.

${ }^{59}$ For example, any policy that constrains the ability of $\mathrm{VC}$ to skim funds or requires exerting costly effort would belong to this category (i.e., leasing land to enterprises or provision of appropriate public goods.)

${ }^{60}$ The results of the model do not change if the implementation of Type I policies also carry a cost component for the VC, as would be the case when the VC lobbies S for the relaxation of an unpopular upper-government policy. To keep the conceptual distinction clean between the two loci of conflict, in what follows we ignore the leader's costs in Type I policies.
} 
implementation. We assume that the value of retaining the village leadership position is $1 .^{61}$

The decision to keep or replace the $\mathrm{VC}$ as a function of the observed outcomes is made by $\mathrm{S}$ before elections are introduced,and by $\mathrm{V}$ and $\mathrm{S}$ after elections. We denote by $\mu$ the weight that V's opinion receives in this decision. Before elections are introduced, $\mu=0$. As discussed in section 2, village elections were imperfectly implemented and the village CCP branch were not directly affected by the electoral reforms. To capture this reality, we assume that after elections are introduced, the upper government continues to decide on the retention of $\mathrm{VC}$ with exogenous probability $1-\mu$. In contrast, with probability $\mu$, the $\mathrm{VC}$ is re-elected according to villagers' votes. This uncertainty from the point of view of the $\mathrm{VC}$ also captures the mutable nature of elections in the first few years of implementation, which are the focus of our analysis. A village with higher $\mu$ is thus one in which the will of the villagers has stronger influence on re-election decisions.

In keeping with the theoretical literature, we consider threshold strategies $k^{\prime}$ and $k^{\prime \prime}$ for villagers and the upper government, respectively, such that at the time of deciding, they retain the $\mathrm{VC}$ if their satisfaction is above the threshold. ${ }^{62}$ Facing these strategies, the VC maximizes

$$
\max _{a, m} \mu \operatorname{Pr}\left(U_{i}^{V} \geq k^{\prime}\right)+(1-\mu) \operatorname{Pr}\left(U^{S} \geq k^{\prime \prime}\right)-l(a)
$$

The following proposition describes how policies change as a result of a shift in accountability.

Proposition 1 As $\mu$ increases, implemented policies react as follows:

1. $m^{*}$ unambiguously increases

2. $a^{*}$ increases if and only if $\sigma_{\theta}^{2}>0$.

Proof. The first-order conditions of the program are

$$
\begin{aligned}
\mu f\left(k^{\prime}-a-m ; \sigma_{\varepsilon}^{2}\right)+(1-\mu)\left(1-c^{\prime}(m)\right) f\left(k^{\prime \prime}-a-m+c(m) ; \sigma_{\varepsilon}^{2}+\sigma_{\theta}^{2}\right) & =0 \\
\mu f\left(k^{\prime}-a-m ; \sigma_{\varepsilon}^{2}\right)+(1-\mu) \frac{\partial u}{\partial b} f\left(k^{\prime \prime}-a-m+c(m) ; \sigma_{\varepsilon}^{2}+\sigma_{\theta}^{2}\right) & =l^{\prime}(a) .
\end{aligned}
$$

where $f($.$) is the pdf of a normal distribution. V$ and $S$ want to maximize their effective weight in the decision taken by the VC. In the face of these reaction functions, the optimal cutoffs for villagers and township are $k^{\prime}=a^{*}+m^{*}$ and $k^{\prime \prime}=a^{*}+m^{*}-c\left(m^{*}\right)$, where $a^{*}$ and $m^{*}$ are the equilibrium

\footnotetext{
${ }^{61}$ Note that this is more than a normalization. The value of holding office might be different across regimes. However, the sign of this difference is far from obvious. If democracy is better at reining in corruption, the value of office will be lower. At the same time, however, the legitimacy that being democratically elected confers might increase the ego-rent component of the value of holding office.

${ }^{62}$ See Alesina and Tabellini (2007) for a recent example and Persson and Tabellini (2000) for a textbook treatment of this type of models.
} 
policies. Hence, the first-order conditions can be rewritten as

$$
\begin{aligned}
\mu \frac{1}{\sqrt{2 \pi}} \frac{1}{\sigma_{\varepsilon}}+(1-\mu)\left(1-c^{\prime}\left(m^{*}\right)\right) \frac{1}{\sqrt{2 \pi}} \frac{1}{\sqrt{\sigma_{\varepsilon}^{2}+\sigma_{\theta}^{2}}}=0 \\
\mu \frac{1}{\sqrt{2 \pi}} \frac{1}{\sigma_{\varepsilon}}+(1-\mu) \frac{1}{\sqrt{2 \pi}} \frac{1}{\sqrt{\sigma_{\varepsilon}^{2}+\sigma_{\theta}^{2}}}=l^{\prime}\left(a^{*}\right) .
\end{aligned}
$$

An examination of these conditions establishes the comparative statics stated in the proposition.

The intuition for these comparative statics is straightforward. As accountability shifts from the $\mathrm{S}$ to the $\mathrm{V}$, the preferences of the latter gain more weight in the re-election decision. It is therefore natural that the VC moves Type I policies in favor of $\mathrm{V}$. The effect on Type II policies is more nuanced because these are policies for which the $\mathrm{S}$ and the $\mathrm{V}$ agree. It is therefore not obvious that shifting accountability should affect policy decisions. In the context of the model, such an effect is only present if $\mathrm{V}$ are better than $\mathrm{S}$ at monitoring the $\mathrm{VC}$. In particular, if $\mathrm{S}$ observes the utility of the $\mathrm{V}$ perfectly, and hence, $\sigma_{\theta}^{2}=0$, then changing the direction of accountability does not make a difference. Needless to say, policies that the VC has no control over should not change as a result of elections. ${ }^{63}$

\section{Data}

Our first source of data is a unique survey collected by the authors. We implemented a retrospective survey of the political reform histories of 217 villages from 1980-2005. Our surveyors gathered all current and former village leaders and respected persons (e.g., teachers) together and asked them to collectively recall the history of reforms. ${ }^{64}$ In general, there was little problem in recalling and forming a consensus on the dates in which elections and other reforms were introduced since these were very important events in the lives of villagers. Moreover, in most villages, surveyors could access administrative records which corroborated villagers' recalled dates. Similarly, history of public investments, land expropriation and exemptions from the One Child Policy were easy to remember for villagers since these were very salient issues. ${ }^{65}$

The second source of data is the NFS, which has been maintained as a panel of villages and households since 1987. The survey used a stratified sampling approach and is supposed to be broadly nationally representative for rural areas. For the household surveys, approximately 100 households are randomly selected to be representative at the village level. Over time, villages and households were added to the sample so that the NFS remained representative. There is little

\footnotetext{
${ }^{63}$ While the model can accommodate several alternative results, it is falsifiable. In particular, the model is not consistent with finding an effect of elections on policies of Type II and no effect on policies of Type I.

${ }^{64}$ Documentation for these data is available at http://www.econ.yale.edu/ nq3/NANCYS_Yale_Website/Surveys.html.

${ }^{65}$ Our information regarding the implementation of the One Child Policy was collected with special care. Since not enforcing an upper-government policy is illegal, we carefully worded our question such that the respondents would not feel wary and answer truthfully. We asked whether all parents in a village in a given year were allowed to have a second child if the first was a girl.
} 
attrition according to the Ministry of Agriculture. ${ }^{66}$

\section{Income and Consumption Results}

In our context, the effect of elections on income is ambiguous. On the one hand, the increase in household land allocation and better provision of public goods can translate into higher income. On the other hand, the reduction in village government controlled land, which is often leased to factories, may decrease villagers' income from enterprises. This is typically earned as wages for villagers who work for the enterprises or as dividends since, in principle, villagers own equal shares of all village assets, including enterprises (Che and Qian, 1998). Since one may suspect that villagers benefit differentially from village enterprises based on their income and education level - e.g., richer households benefit more either because they are able to contribute more in the production of the enterprises or because they are better able to capture the profits - we examine the effect of elections on income for the entire within-village income distribution.

Appendix Table A4 rows (1)-(6) show the estimates from our baseline equation for the effect of elections on log total household gross income by income quantile. The estimates are negative in sign for households above the bottom quartile in income and increasing in magnitude (in terms of absolute value) for richer households. However, they are not statistically significant. The estimates in rows (7)-(12) suggest that elections reduce income from enterprises for the richest households. But these estimates are not statistically significant. Rows (13)-(18) show that elections reduce wage income for richer households. However, they are also statistically insignificant for the most part. ${ }^{67}$ The results presented here are not conclusive, due to lack of precision. But the patterns of the coefficients are consistent with our finding that elections shift land from being leased to factories to being farmed by households.

\footnotetext{
${ }^{66}$ For a detailed description of the NFS, please see http://www.econ.yale.edu/ nq3/NANCYS_Yale_Website/Research.html

${ }^{67}$ Note that we can only examine enterprise and wage incomes for households in the upper income percentiles because poor households in our sample do not earn income from these sources.

To address the possibility that elections cause rich households to fear expropriation and thereby to under-report their incomes, we repeat the estimation with total household consumption as the dependent variable. Rows (19)(24) show that we find a similar pattern for consumption across income quantiles. The magnitudes of the estimates are very similar to those for the reduction in total household income. However, the estimates are not statistically significant. We interpret these results as suggestive evidence that our income data does not suffer from systematic under-reporting by the rich after elections were introduced.
} 
Table 1: Descriptive Statistics

\begin{tabular}{|c|c|c|c|c|c|c|c|}
\hline Variable & Obs & Mean & Std. Dev. & Variable & Obs & Mean & Std. Dev. \\
\hline A. Full Sample of Village & & & & B. Subsample of Villages with Household Data & & & \\
\hline \# of $\mathrm{HH}$ in Village & 3291 & 419.769 & 279.765 & \# of $\mathrm{HH}$ in Village & 1121 & 449.771 & 279.265 \\
\hline Fraction of the Largest Kinship Clans & 4992 & 0.523 & 0.238 & Median HH Gross Income (RMB) & 1297 & 11391.210 & 10519.790 \\
\hline Jiapu (Family Tree) & 5208 & 0.097 & 0.296 & Median HH Gross Income Growth & 1133 & 0.095 & 0.226 \\
\hline Citang (Ancetral Hall) & 5208 & 0.034 & 0.181 & Median HH Income/90th Percentile HH Income & 1297 & 0.512 & 0.130 \\
\hline Near City & 5208 & 0.088 & 0.284 & 10th Percentile HH Income/Median HH Income & 1297 & 0.503 & 0.125 \\
\hline Land was Expropriated by Upper Government & 5208 & 0.036 & 0.187 & Median HH Arable Farm Land (Mu) & 1297 & 5.224 & 6.054 \\
\hline Allow a 2nd Child if the 1 st is a Girl & 5208 & 0.501 & 0.500 & Median HH Land/90th Percentile Land (Mu) & 1264 & 0.573 & 0.142 \\
\hline Village Investment into Public Goods (10,000 RMB) & 5208 & 9.180 & 89.776 & 10th Percentile HH Land/50th Percentile HH Land (Mu) & 1235 & 0.356 & 0.238 \\
\hline for Schools & 5208 & 1.330 & 15.596 & Median HH Payment of Village and County Fees and Levies (100 RMB) & 1297 & 3.197 & 3.081 \\
\hline for Roads and Sanitation & 5208 & 2.645 & 58.234 & & & & \\
\hline for Electricity & 5208 & 0.615 & 7.174 & C. Government & & & \\
\hline for Irrigation & 5208 & 1.706 & 36.543 & The Number of Village Committee Members & 2287 & 4.365 & 2.360 \\
\hline for Planting Trees & 5208 & 0.189 & 6.050 & The Number of Village Party Cadres & 2295 & 6.698 & 3.815 \\
\hline for Other & 5208 & 1.791 & 44.092 & Village Chief Tenure & 5208 & 6.688 & 6.238 \\
\hline Public Investment funded by Villagers & 5208 & 6.270 & 92.484 & Party Secretary Tenure & 5208 & 10.032 & 8.126 \\
\hline $\begin{array}{l}\text { Public Investment funded by Upper Levels of } \\
\text { Government }\end{array}$ & 5208 & 3.029 & 55.973 & & & & \\
\hline Total Village Land $(\mathrm{Mu})$ & 3291 & $9,130.517$ & $14,831.330$ & D. Elections & & & \\
\hline Total Village Arable Land (Mu) & 3291 & $2,273.782$ & $2,309.547$ & 1st Election in Village & 5208 & 1988.512 & 5.240 \\
\hline Arable HH Farm Land (Mu) & 3291 & $2,196.106$ & $2,291.943$ & 1st Competitive Election (e.g., >1 candidate per position) & 5112 & 1991.873 & 6.426 \\
\hline As a fraction of total arable land & 3291 & 0.959 & 0.152 & 1st Election with Open Nomination of Candidates & 3336 & 1997.446 & 5.256 \\
\hline Arable Collective Land $(\mathrm{Mu})$ & 3291 & 33.799 & 233.408 & Years between 1st Election in Village and Province Implementation & 5208 & 4.963 & 5.062 \\
\hline As a fraction of total arable land & 3291 & 0.016 & 0.095 & Years between 1st Election in County and Province Implementation & 4416 & 5.299 & 5.010 \\
\hline Arable Land Leased to Village Enterprises $(\mathrm{Mu})$ & 3291 & 25.453 & 251.757 & Years between 1st Election in Village and County Implementation* & 4416 & -0.141 & 3.962 \\
\hline As a fraction of total arable land & 3291 & 0.010 & 0.074 & Anonymous Voting & 1281 & 0.848 & 0.359 \\
\hline Median HH Gross Income (RMB) & 3778 & 10512.980 & 8365.713 & Proxy Voting & 1265 & 0.721 & 0.449 \\
\hline Median HH Annual Gross Income Growth & 3165 & 0.092 & 0.218 & Roving Ballot Box & 1251 & 0.652 & 0.476 \\
\hline Median HH Income/90th Percentile HH Income & 3778 & 0.529 & 0.123 & There were more than 2 Candidates per Position & 1293 & 0.791 & 0.407 \\
\hline 10th Percentile HH Income/Median HH Income & 3778 & 0.509 & 0.124 & Years between Elections & 1084 & 3.162 & 1.024 \\
\hline
\end{tabular}

Notes: Observations are at the village-year level. ${ }^{*}$ The first election in the county excludes the respondent village. 
Table 2: The Distribution of Leader Powers

\begin{tabular}{lcc}
\hline \hline \multicolumn{1}{c}{ Signature Rights } & Mean & Std. Dev. \\
\hline Appoint managers of village enterprises: & & 0.468 \\
Village Chief & 0.323 & 0.461 \\
Party Secretary & 0.307 & 0.482 \\
Village Chief \& Party Secretary & 0.368 & \\
Employ village government public employees: & & 0.442 \\
Village Chief & 0.266 & 0.456 \\
Party Secretary & 0.294 & 0.496 \\
Village Chief \& Party Secretary & 0.439 & \\
Reimbursement: & & 0.497 \\
Village Chief & & 0.432 \\
Party Secretary & 0.558 & 0.395 \\
Village Chief \& Party Secretary & 0.248 & \\
Reallocate Land: & 0.193 & \\
Village Chief & & 0.470 \\
Party Secretary & & 0.341 \\
Village Chief \& Party Secretary & 0.329 & 0.499 \\
Large Public Investment: & 0.135 & \\
Village Chief & 0.530 & \\
Party Secretary & & 0.382 \\
Village Chief \& Party Secretary & & 0.357 \\
\hline Notes: Obsergtions are at the villge-year & 0.177 & 0.469 \\
\hline
\end{tabular}

Notes: Observations are at the village-year level.

Table 3: Elections and Leader Powers

\begin{tabular}{|c|c|c|c|c|c|c|c|c|c|c|}
\hline & & \multicolumn{9}{|c|}{ Dependent Variables: De Facto Powers of Village Leaders } \\
\hline & & & \multicolumn{2}{|c|}{ Post 1st Election } & \multicolumn{2}{|c|}{$\begin{array}{c}\text { Post 1st } \\
\text { Competitive } \\
\text { Election } \\
\end{array}$} & \multicolumn{2}{|c|}{$\begin{array}{l}\text { Post 1st Open } \\
\text { Nomination }\end{array}$} & \multirow[b]{2}{*}{ Obs } & \multirow[b]{2}{*}{$\mathrm{R}^{2}$} \\
\hline & & & Coeff & Std Err & Coeff & Std Err & Coeff & Std Err & & \\
\hline & (1) & Appoint TVE Manager & 0.065 & $(0.039)$ & -0.028 & $(0.035)$ & -0.033 & $(0.042)$ & 3,336 & 0.801 \\
\hline Unilateral & (2) & Employ Village Staff & 0.047 & $(0.038)$ & -0.021 & $(0.037)$ & -0.018 & $(0.038)$ & 4,103 & 0.785 \\
\hline VC & (3) & Reimbursement & 0.051 & (0.038) & -0.024 & $(0.034)$ & -0.053 & $(0.040)$ & 4,910 & 0.771 \\
\hline \multirow[t]{3}{*}{ Power } & (4) & Land Reallocation & 0.076 & $(0.035)$ & -0.045 & $(0.0310)$ & -0.007 & $(0.039)$ & 3,936 & 0.800 \\
\hline & (5) & Public Investment & 0.073 & $(0.027)$ & -0.049 & $(0.025)$ & 0.010 & $(0.034)$ & 4,457 & 0.780 \\
\hline & (6) & Appoint TVE Manager & 0.001 & $(0.039)$ & -0.0002 & $(0.039)$ & 0.023 & $(0.044)$ & 3,336 & 0.797 \\
\hline Joint VC & (7) & Employ Village Staff & -0.025 & $(0.041)$ & 0.034 & $(0.042)$ & 0.048 & $(0.044)$ & 4,103 & 0.769 \\
\hline PC & (8) & Reimbursement & 0.014 & (0.030) & 0.001 & $(0.030)$ & 0.062 & $(0.038)$ & 4,910 & 0.724 \\
\hline \multirow[t]{3}{*}{ Power } & (9) & Land Reallocation & -0.002 & (0.039) & -0.010 & $(0.033)$ & 0.026 & $(0.041)$ & 3,936 & 0.804 \\
\hline & (10) & Public Investment & -0.024 & $(0.031)$ & -0.005 & $(0.027)$ & 0.019 & $(0.038)$ & 4,457 & 0.808 \\
\hline & (11) & Appoint TVE Manager & -0.067 & $(0.035)$ & 0.027 & $(0.031)$ & 0.022 & $(0.035)$ & 3,336 & 0.832 \\
\hline Unilateral & (12) & Employ Village Staff & -0.023 & $(0.031)$ & -0.013 & $(0.030)$ & -0.030 & $(0.034)$ & 4,103 & 0.819 \\
\hline PS & (13) & Reimbursement & -0.066 & $(0.027)$ & 0.023 & $(0.023)$ & -0.009 & $(0.032)$ & 4,910 & 0.810 \\
\hline \multirow[t]{2}{*}{ Power } & (14) & Land Reallocation & -0.075 & (0.031) & 0.054 & $(0.021)$ & -0.019 & $(0.031)$ & 3,936 & 0.799 \\
\hline & (15) & Public Investment & -0.050 & $(0.029)$ & 0.053 & $(0.021)$ & -0.029 & $(0.030)$ & 4,457 & 0.775 \\
\hline
\end{tabular}

Notes: All regressions control for province-time trends, village and year fixed effects. Standard errors are clustered at the village level. 
Table 4: The Effect of Elections on Type I, III Policies

\begin{tabular}{|c|c|c|c|c|}
\hline & \multicolumn{4}{|c|}{ Dependent Variables } \\
\hline & \multicolumn{2}{|c|}{ Type I: Unpopular Policies } & \multicolumn{2}{|c|}{ Type III: Placebo Outcomes } \\
\hline & $\begin{array}{l}\text { Dummy for Allowing a } \\
\text { 2nd Child if the 1st is a } \\
\text { Girl } \\
\text { (1) }\end{array}$ & $\begin{array}{c}\text { Dummy for Upper } \\
\text { Government } \\
\text { Expropriation of Village } \\
\text { Land } \\
\text { (2) }\end{array}$ & $\begin{array}{l}\text { Ln Public Investment } \\
\text { from Special Aid } \\
\text { (3) }\end{array}$ & $\begin{array}{c}\text { Ln Distance to Nearest } \\
\text { Highschool } \\
(4)\end{array}$ \\
\hline $\begin{array}{l}\text { Post 1st Competitive } \\
\text { Election }\end{array}$ & $\begin{array}{c}0.006 \\
(0.032)\end{array}$ & $\begin{array}{c}0.010 \\
(0.011)\end{array}$ & $\begin{array}{c}0.002 \\
(0.029)\end{array}$ & $\begin{array}{l}-0.028 \\
(0.017)\end{array}$ \\
\hline Post 1st Open Nomination & $\begin{array}{l}-0.053 \\
(0.035)\end{array}$ & $\begin{array}{l}-0.007 \\
(0.011)\end{array}$ & $\begin{array}{c}0.008 \\
(0.024)\end{array}$ & $\begin{array}{l}-0.029 \\
(0.025)\end{array}$ \\
\hline
\end{tabular}

Notes: All regressions control for province-time trends, village fixed effects, and year fixed effects. Standard errors are clustered at the village level.

Table 5: The Effect of Elections on Public Goods Investment (Type II)

\begin{tabular}{|c|c|c|c|c|c|c|c|}
\hline & \multicolumn{7}{|c|}{ Dependent Variables } \\
\hline & $\begin{array}{l}\text { Total } \\
\text { (1) }\end{array}$ & $\begin{array}{c}\text { Villagers } \\
\text { (2) }\end{array}$ & $\begin{array}{l}\text { Upper- } \\
\text { Gov } \\
\text { Special } \\
\text { Aid } \\
(3)\end{array}$ & $\begin{array}{l}\text { Upper- } \\
\text { Gov } \\
\text { Other } \\
(4)\end{array}$ & $\begin{array}{l}\text { Other } \\
(5)\end{array}$ & $\begin{array}{l}\text { Upper- } \\
\text { Gov Sum } \\
\text { (6) }\end{array}$ & $\begin{array}{c}\text { All Non } \\
\text { Village } \\
(7)\end{array}$ \\
\hline & \multicolumn{7}{|c|}{ A. Ln Total Public Investment } \\
\hline Post 1st Election & $\begin{array}{c}0.175 \\
(0.114)\end{array}$ & $\begin{array}{l}0.0849 \\
(0.096)\end{array}$ & $\begin{array}{l}0.0045 \\
(0.025)\end{array}$ & $\begin{array}{l}0.0448 \\
(0.047)\end{array}$ & $\begin{array}{c}-0.0112 \\
(0.034)\end{array}$ & $\begin{array}{l}0.0464 \\
(0.054)\end{array}$ & $\begin{array}{l}0.0488 \\
(0.065)\end{array}$ \\
\hline Observations & 5,208 & 5,208 & 5,208 & 5,208 & 5,208 & 5,208 & 5,208 \\
\hline \multirow{2}{*}{$\mathrm{R}^{2}$} & 0.199 & 0.176 & 0.079 & 0.161 & 0.120 & 0.157 & 0.173 \\
\hline & \multicolumn{7}{|c|}{ B. Irrigation } \\
\hline Post 1st Election & $\begin{array}{c}-2.446 \\
(1.265)\end{array}$ & $\begin{array}{c}-1.599 \\
(1.191)\end{array}$ & $\begin{array}{l}-0.472 \\
(0.268)\end{array}$ & $\begin{array}{c}0.330 \\
(0.816)\end{array}$ & $\begin{array}{l}-0.097 \\
(0.096)\end{array}$ & $\begin{array}{c}-0.142 \\
(0.876)\end{array}$ & $\begin{array}{l}-0.238 \\
(0.868)\end{array}$ \\
\hline Post 1st Election x Avg Ln HH Farm Land & $\begin{array}{c}0.374 \\
(0.165)\end{array}$ & $\begin{array}{c}0.236 \\
(0.160)\end{array}$ & $\begin{array}{c}0.067 \\
(0.037)\end{array}$ & $\begin{array}{l}-0.029 \\
(0.113)\end{array}$ & $\begin{array}{c}0.011 \\
(0.009)\end{array}$ & $\begin{array}{c}0.038 \\
(0.122)\end{array}$ & $\begin{array}{c}0.049 \\
(0.121)\end{array}$ \\
\hline Observations & 5,208 & 5,208 & 5,208 & 5,208 & 5,208 & 5,208 & 5,208 \\
\hline \multirow[t]{2}{*}{$\mathrm{R}^{2}$} & 0.106 & 0.106 & 0.058 & 0.109 & 0.065 & 0.106 & 0.106 \\
\hline & \multicolumn{7}{|c|}{ C. Schooling* } \\
\hline Post 1st Election & $\begin{array}{c}-2.898 \\
(15.550)\end{array}$ & $\begin{array}{c}6.273 \\
(13.470)\end{array}$ & $\begin{array}{l}-0.509 \\
(3.660)\end{array}$ & $\begin{array}{c}-2.633 \\
(5.109)\end{array}$ & $\begin{array}{c}-0.963 \\
(3.257)\end{array}$ & $\begin{array}{c}-3.142 \\
(5.528)\end{array}$ & $\begin{array}{l}-4.105 \\
(6.021)\end{array}$ \\
\hline Post 1st Election x \# Kids 7-13 & $\begin{array}{c}0.013 \\
(0.005)\end{array}$ & $\begin{array}{c}0.015 \\
(0.006)\end{array}$ & $\begin{array}{c}0.000 \\
(0.001)\end{array}$ & $\begin{array}{l}-0.001 \\
(0.002)\end{array}$ & $\begin{array}{l}0.0002 \\
(0.001)\end{array}$ & $\begin{array}{l}-0.002 \\
(0.002)\end{array}$ & $\begin{array}{l}-0.001 \\
(0.002)\end{array}$ \\
\hline Observations & 5,064 & 5,064 & 5,064 & 5,064 & 5,064 & 5,064 & 5,064 \\
\hline $\mathrm{R}^{2}$ & 0.077 & 0.069 & 0.057 & 0.108 & 0.062 & 0.099 & 0.086 \\
\hline
\end{tabular}

Notes: *The coefficients for the estimates on public investment in schooling are scaled by 1,000 for ease of interpretation.

All regressions control for post first competitive election, post first open nomination, province-time trends, village and year fixed effects. The regressions in Panels $B$ and $C$ also control for the interaction of the relevant village characteristic (e.g., number of kids age 7-13, In total household farm land) with post first competitive election and post first open nominations. Standard errors are clustered at the village level. 
Table 6: The Effect of Elections on Household Land Allocation (Type II)

\begin{tabular}{|c|c|c|c|c|c|c|c|c|c|c|c|}
\hline & \multicolumn{11}{|c|}{ Dependent Variables: Village Land Distribution } \\
\hline & \multicolumn{9}{|c|}{ Quantile of Within-village Household Land Distribution } & \multicolumn{2}{|c|}{$\begin{array}{c}\text { Land Managed by the } \\
\text { Village Government }\end{array}$} \\
\hline & 10th & 20th & 30th & 40th & 50th & 60th & 70th & 80th & 90th & $\begin{array}{c}\text { Ln Land } \\
\text { Leased } \\
\text { Out to } \\
\text { Firms, } \\
\text { Land } \\
\text { Leased } \\
\text { Out }>0\end{array}$ & $\begin{array}{l}\text { Ln Land } \\
\text { Managed } \\
\text { by } \\
\text { Collectively, } \\
\text { Collective } \\
\text { Land >0 }\end{array}$ \\
\hline & $(1)$ & $(2)$ & (3) & $(4)$ & $(5)$ & $(6)$ & $(7)$ & $(8)$ & (9) & $(10)$ & (11) \\
\hline Post 1st Election & $\begin{array}{l}0.00608 \\
(0.222)\end{array}$ & $\begin{array}{c}0.248 \\
(0.203)\end{array}$ & $\begin{array}{c}0.257 \\
(0.172)\end{array}$ & $\begin{array}{c}0.280 \\
(0.150)\end{array}$ & $\begin{array}{c}0.253 \\
(0.117)\end{array}$ & $\begin{array}{c}0.203 \\
(0.113)\end{array}$ & $\begin{array}{c}0.162 \\
(0.109)\end{array}$ & $\begin{array}{c}0.113 \\
(0.103)\end{array}$ & $\begin{array}{l}0.0969 \\
(0.105)\end{array}$ & $\begin{array}{l}-0.679 \\
(0.388)\end{array}$ & $\begin{array}{l}-0.718 \\
(0.405)\end{array}$ \\
\hline Post 1st Competitive Election & $\begin{array}{l}0.0537 \\
(0.195)\end{array}$ & $\begin{array}{l}-0.262 \\
(0.183)\end{array}$ & $\begin{array}{l}-0.101 \\
(0.138)\end{array}$ & $\begin{array}{l}-0.0478 \\
(0.128)\end{array}$ & $\begin{array}{l}-0.0188 \\
(0.0924)\end{array}$ & $\begin{array}{l}0.00816 \\
(0.0843)\end{array}$ & $\begin{array}{c}0.0245 \\
(0.0857)\end{array}$ & $\begin{array}{l}0.0503 \\
(0.0923)\end{array}$ & $\begin{array}{c}0.0600 \\
(0.0996)\end{array}$ & $\begin{array}{l}-0.103 \\
(0.455)\end{array}$ & $\begin{array}{c}0.178 \\
(0.422)\end{array}$ \\
\hline Post 1st Open Nomination & $\begin{array}{l}-0.102 \\
(0.182)\end{array}$ & $\begin{array}{l}-0.144 \\
(0.147)\end{array}$ & $\begin{array}{l}-0.263 \\
(0.153)\end{array}$ & $\begin{array}{l}-0.128 \\
(0.122)\end{array}$ & $\begin{array}{l}-0.106 \\
(0.103)\end{array}$ & $\begin{array}{r}-0.0834 \\
(0.106)\end{array}$ & $\begin{array}{l}-0.0385 \\
(0.0929)\end{array}$ & $\begin{array}{c}0.0318 \\
(0.0812)\end{array}$ & $\begin{array}{c}0.101 \\
(0.0821)\end{array}$ & $\begin{array}{l}0.387 \\
(0.388)\end{array}$ & $\begin{array}{l}-0.102 \\
(0.372)\end{array}$ \\
\hline Observations & 1297 & 1297 & 1297 & 1297 & 1297 & 1297 & 1297 & 1297 & 1297 & 315 & 501 \\
\hline R-squared & 0.735 & 0.792 & 0.808 & 0.857 & 0.884 & 0.890 & 0.888 & 0.882 & 0.881 & 0.927 & 0.845 \\
\hline
\end{tabular}

Notes: All regressions control for province-time trends, village and year fixed effects. Standard errors are clustered at the village level. Regressions in columns (1)-(9) use the household data subsample. Regressions in columns (10)-(11) use subsamples of villages from the full 217 village sample. Column (10) includes villages-years that lease some land to firms. Column (11) includes village-years that have some land managed by the collectives. 
Table 7: The 2SLS Estimates of the Effect of Elections - Robustness to Within-County Heterogeneity

\begin{tabular}{|c|c|c|c|c|c|c|c|c|c|c|c|}
\hline & \multicolumn{11}{|c|}{ Dependent Variables } \\
\hline & $\begin{array}{l}\text { Post 1st } \\
\text { Election }\end{array}$ & $\begin{array}{l}\text { Post 1st } \\
\text { Election }\end{array}$ & $\begin{array}{l}\text { Post 1st } \\
\text { Open } \\
\text { Nomination }\end{array}$ & $\begin{array}{r}\text { Land Ex } \\
\text { Du }\end{array}$ & $\begin{array}{l}\text { ropriation } \\
\text { nmy }\end{array}$ & $\begin{array}{r}\text { Dummy f } \\
\text { a 2nd } \\
1 \text { st is }\end{array}$ & $\begin{array}{l}r \text { Allowing } \\
\text { iild if the } \\
\text { a Girl }\end{array}$ & $\begin{array}{l}\text { Ln Public I } \\
\text { Irrigation } \mathrm{f}\end{array}$ & $\begin{array}{l}\text { ivestment in } \\
\text { om Villagers }\end{array}$ & $\begin{array}{l}\text { Ln Public } \\
\text { Schooling }\end{array}$ & $\begin{array}{l}\text { Ivestment in } \\
\text { om Villagers }\end{array}$ \\
\hline & $\begin{array}{l}\text { 1st Stage (1 } \\
\text { Instrument) } \\
(1)\end{array}$ & $\begin{array}{l}\text { 1st Stage (2 } \\
\text { Instruments) }\end{array}$ & $\begin{array}{c}\text { 1st Stage (2 } \\
\text { Instruments) } \\
(3)\end{array}$ & $\begin{array}{c}\text { IV for } \\
\text { Post } \\
1 \text { st } \\
\text { Election } \\
\\
(4) \\
\end{array}$ & $\begin{array}{l}\text { IV for } \\
\text { Post 1st } \\
\text { Election, } \\
\text { Post 1st } \\
\text { Open } \\
\text { Nom. } \\
(5)\end{array}$ & $\begin{array}{c}\text { IV for } \\
\text { Post 1st } \\
\text { Election } \\
(6)\end{array}$ & $\begin{array}{l}\text { IV for } \\
\text { Post 1st } \\
\text { Election, } \\
\text { Post 1st } \\
\text { Open } \\
\text { Nom. } \\
(7)\end{array}$ & $\begin{array}{l}\text { IV for Post } \\
1 \text { st } \\
\text { Election \& } \\
\text { Interaction } \\
\text { (8) }\end{array}$ & $\begin{array}{c}\text { IV for Post } \\
1 \mathrm{st} \\
\text { Election, } \\
\text { Post 1st } \\
\text { Open Nom. } \\
\& \\
\text { Interactions } \\
(9) \\
\end{array}$ & $\begin{array}{c}\text { IV for Post } \\
\text { 1st } \\
\text { Election \& } \\
\text { Interaction } \\
\\
(10)\end{array}$ & $\begin{array}{c}\text { IV for Post } \\
1 \text { st } \\
\text { Election, } \\
\text { Post } 1 \mathrm{st} \\
\text { Open Nom. } \\
\& \\
\text { Interactions } \\
(11) \\
\end{array}$ \\
\hline Post 1st Election in County & $\begin{array}{l}0.288 \\
(0.031)\end{array}$ & $\begin{array}{l}0.287 \\
(0.031)\end{array}$ & $\begin{array}{c}0.006 \\
(0.030)\end{array}$ & & & & & & & & \\
\hline $\begin{array}{l}\text { Post 1st Open Nomination } \\
\text { in County }\end{array}$ & & $\begin{array}{c}0.016 \\
(0.025)\end{array}$ & $\begin{array}{c}0.176 \\
(0.041)\end{array}$ & & & & & & & & \\
\hline Post 1st Election & & & & $\begin{array}{l}-0.053 \\
(0.029)\end{array}$ & $\begin{array}{l}-0.057 \\
(0.031)\end{array}$ & $\begin{array}{c}0.294 \\
(0.111)\end{array}$ & $\begin{array}{c}0.303 \\
(0.119)\end{array}$ & $\begin{array}{c}19.470 \\
(40.180)\end{array}$ & $\begin{array}{c}16.190 \\
(38.660)\end{array}$ & $\begin{array}{l}-1.753 \\
(1.824)\end{array}$ & $\begin{array}{l}-2.052 \\
(2.206)\end{array}$ \\
\hline Post 1st Open Nomination & $\begin{array}{l}-0.021 \\
(0.022)\end{array}$ & & & $\begin{array}{l}-0.007 \\
(0.011)\end{array}$ & $\begin{array}{c}0.019 \\
(0.063)\end{array}$ & $\begin{array}{l}-0.052 \\
(0.035)\end{array}$ & $\begin{array}{l}-0.111 \\
(0.184)\end{array}$ & $\begin{array}{l}-10.740 \\
(26.070)\end{array}$ & $\begin{array}{c}15.000 \\
(107.900)\end{array}$ & $\begin{array}{l}-0.039 \\
(0.832)\end{array}$ & $\begin{array}{l}2.304 \\
(3.047)\end{array}$ \\
\hline $\begin{array}{l}\text { Post 1st Competitive } \\
\text { Election }\end{array}$ & $\begin{array}{c}0.476 \\
(0.037)\end{array}$ & $\begin{array}{c}0.473 \\
(0.037)\end{array}$ & $\begin{array}{c}0.129 \\
(0.029)\end{array}$ & $\begin{array}{c}0.029 \\
(0.018)\end{array}$ & $\begin{array}{c}0.028 \\
(0.019)\end{array}$ & $\begin{array}{l}-0.109 \\
(0.063)\end{array}$ & $\begin{array}{l}-0.105 \\
(0.063)\end{array}$ & $\begin{array}{l}-14.430 \\
(26.370)\end{array}$ & $\begin{array}{l}-15.760 \\
(25.890)\end{array}$ & $\begin{array}{c}1.551 \\
(1.928)\end{array}$ & $\begin{array}{c}1.361 \\
(1.943)\end{array}$ \\
\hline $\begin{array}{l}\text { Post st Election } x \\
\text { Avg \# of Kids 7-13 in Village }\end{array}$ & & & & & & & & $\begin{array}{l}0.014 \\
(0.005)\end{array}$ & $\begin{array}{l}0.014 \\
(0.005)\end{array}$ & & \\
\hline $\begin{array}{l}\text { Post 1st Election x } \\
\text { Avg Ln HH Arable Land }\end{array}$ & & & & & & & & & & $\begin{array}{c}0.285 \\
(0.240)\end{array}$ & $\begin{array}{c}0.315 \\
(0.276)\end{array}$ \\
\hline Observations & 5,208 & 5,208 & 5,208 & 5,208 & 5,208 & 5,208 & 5,208 & 5,064 & 5,064 & 5,208 & 5,208 \\
\hline
\end{tabular}

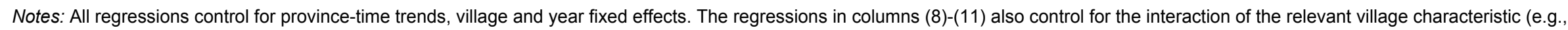
number of kids age 7-13, log total household farmland) with post first competitive election and post first open nominations. The interaction terms are instrumented by the interaction of the

introduction of elections and open nominations in the county and the same relevant characteristics. Standard errors are clustered at the village level. 


\section{Table 8: The Effect of Elections - Robustness to Omitted Factors}

\begin{tabular}{|c|c|c|c|c|c|c|c|c|c|c|c|c|c|c|c|}
\hline & Baseline & $\begin{array}{c}\text { Avg } \\
\text { Median } \\
\text { HH } \\
\text { Land X } \\
\text { Year } \\
\text { FE* }^{\star}\end{array}$ & $\begin{array}{c}\text { Avg } \\
\text { Land50/90 } \\
\times \text { Year } \\
\mathrm{FE}^{*}\end{array}$ & $\begin{array}{c}\text { Avg Ln } \\
\text { Total } \\
\text { HH } \\
\text { Land } x \\
\text { Year } \\
\text { FE }\end{array}$ & $\begin{array}{l}\text { Avg Ln } \\
\text { Land } \\
\text { Lease } x \\
\text { Year FE }\end{array}$ & $\begin{array}{l}\text { Avg Land } \\
\text { Expropriation } \\
\text { x Year FE }\end{array}$ & $\begin{array}{c}\text { Near } \\
\text { City } x \\
\text { Year } \\
\text { FE }\end{array}$ & $\begin{array}{c}\text { Avg Ln } \\
\text { Median } \\
\text { HH } \\
\text { Fee x } \\
\text { Year } \\
\text { FE }^{*}\end{array}$ & $\begin{array}{l}\text { Avg } \\
\text { Fertility } \\
x \text { Year } \\
\text { FE }\end{array}$ & $\begin{array}{l}\text { Avg } \\
\text { Labor- } \\
\text { Pop } \\
\text { Ratio x } \\
\text { Year } \\
\text { FE }\end{array}$ & $\begin{array}{c}\text { Avg } \\
\text { Exemption } \\
\text { OCP } x \\
\text { Year FE }\end{array}$ & $\begin{array}{c}\text { Avg Ln } \\
\text { Median } \\
\text { HH Inc } \\
\text { x Year } \\
\text { FE }\end{array}$ & $\begin{array}{c}\text { Avg } \\
\text { Inc50/90 } \\
\times \text { Year } \\
\text { FE }\end{array}$ & $\begin{array}{l}\text { Avg } \\
\text { Med } \\
\text { Inc } \\
\text { Growth } \\
\text { x Year } \\
\text { FE }\end{array}$ & $\begin{array}{c}\text { Controls } \\
\text { from } \\
\text { columns } \\
(2)-(8) \text {, } \\
(10)- \\
(14)^{\star}\end{array}$ \\
\hline & (1) & (2) & (3) & (4) & (5) & (6) & (7) & (8) & (9) & (10) & (11) & (12) & (13) & (14) & (15) \\
\hline & \multicolumn{15}{|c|}{ A. Dependent Variable: Ln Median HH Land } \\
\hline \multirow[t]{2}{*}{ Post 1st Election } & 0.253 & 0.207 & 0.240 & 0.253 & 0.260 & 0.224 & 0.253 & 0.253 & 0.286 & 0.276 & 0.257 & 0.304 & 0.252 & 0.254 & 0.220 \\
\hline & $(0.117)$ & $(0.129)$ & $(0.114)$ & $(0.117)$ & $(0.116)$ & $(0.105)$ & $(0.117)$ & $(0.117)$ & $(0.112)$ & $(0.120)$ & $(0.115)$ & $(0.102)$ & $(0.114)$ & $(0.119)$ & $(0.105)$ \\
\hline Obs & 1,297 & 1,297 & 1,297 & 1,297 & 1,297 & 1,297 & 1,297 & 1,297 & 1,297 & 1,297 & 1,297 & 1,297 & 1,297 & 1,297 & 1,297 \\
\hline \multirow[t]{2}{*}{$\mathrm{R}^{2}$} & 0.884 & 0.904 & 0.896 & 0.884 & 0.888 & 0.898 & 0.884 & 0.884 & 0.883 & 0.888 & 0.885 & 0.900 & 0.891 & 0.885 & 0.928 \\
\hline & \multicolumn{15}{|c|}{ B. Dependent Variable: Ln Median HH Fees and Levies } \\
\hline \multirow[t]{2}{*}{ Post 1st Election } & 0.956 & 0.810 & 0.879 & 0.956 & 0.980 & 0.938 & 0.956 & 0.956 & 0.989 & 0.990 & 0.931 & 0.860 & 0.890 & 0.957 & 0.693 \\
\hline & $(0.503)$ & $(0.514)$ & $(0.505)$ & $(0.503)$ & $(0.507)$ & $(0.496)$ & $(0.503)$ & $(0.503)$ & $(0.539)$ & $(0.507)$ & $(0.510)$ & $(0.516)$ & $(0.511)$ & $(0.510)$ & $(0.514)$ \\
\hline Obs & 1,297 & 1,297 & 1,297 & 1,297 & 1,297 & 1,297 & 1,297 & 1,297 & 1,297 & 1,297 & 1,297 & 1,297 & 1,297 & 1,297 & 1,297 \\
\hline \multirow[t]{2}{*}{$\mathrm{R}^{2}$} & 0.610 & 0.616 & 0.617 & 0.610 & 0.616 & 0.615 & 0.610 & 0.610 & 0.619 & 0.616 & 0.618 & 0.614 & 0.616 & 0.613 & 0.664 \\
\hline & \multicolumn{15}{|c|}{ C. Dependent Variable: Upper Government Land Expropriation } \\
\hline \multirow[t]{2}{*}{ Post 1st Election } & -0.018 & -0.044 & -0.041 & -0.018 & -0.017 & -0.018 & -0.050 & -0.018 & -0.016 & -0.017 & -0.018 & -0.017 & -0.017 & -0.018 & -0.014 \\
\hline & $(0.011)$ & $(0.018)$ & $(0.017)$ & $(0.011)$ & $(0.011)$ & $(0.010)$ & $(0.022)$ & $(0.011)$ & $(0.011)$ & $(0.011)$ & $(0.011)$ & $(0.011)$ & $(0.011)$ & $(0.011)$ & $(0.010)$ \\
\hline Obs & 5,208 & 1,752 & 1,752 & 5,208 & 5,208 & 5,208 & 1,297 & 5,208 & 5,064 & 5,208 & 5,208 & 5,208 & 5,208 & 5,208 & 5,208 \\
\hline \multirow[t]{2}{*}{$\mathrm{R}^{2}$} & 0.080 & 0.094 & 0.091 & 0.080 & 0.082 & 0.087 & 0.101 & 0.080 & 0.087 & 0.083 & 0.083 & 0.083 & 0.085 & 0.082 & 0.125 \\
\hline & \multicolumn{15}{|c|}{ D. Dependent Variable: Dummy for Allowing a 2nd Child if the 1 st is a Girl } \\
\hline \multirow[t]{2}{*}{ Post 1st Election } & 0.082 & 0.174 & 0.196 & 0.082 & 0.086 & 0.082 & 0.178 & 0.082 & 0.072 & 0.084 & 0.086 & 0.081 & 0.083 & 0.083 & 0.097 \\
\hline & $(0.040)$ & $(0.077)$ & $(0.078)$ & $(0.040)$ & $(0.040)$ & $(0.040)$ & $(0.099)$ & $(0.040)$ & $(0.040)$ & $(0.040)$ & $(0.039)$ & $(0.040)$ & $(0.039)$ & $(0.040)$ & $(0.040)$ \\
\hline Obs & 5,208 & 1,752 & 1,752 & 5,208 & 5,208 & 5,208 & 1,297 & 5,208 & 5,064 & 5,208 & 5,208 & 5,208 & 5,208 & 5,208 & 5,208 \\
\hline \multirow[t]{2}{*}{$\mathrm{R}^{2}$} & 0.755 & 0.739 & 0.737 & 0.755 & 0.756 & 0.755 & 0.758 & 0.755 & 0.757 & 0.757 & 0.762 & 0.755 & 0.757 & 0.756 & 0.771 \\
\hline & \multicolumn{15}{|c|}{ E. Dependent Variable: Ln Total Public Investment } \\
\hline \multirow[t]{2}{*}{ Post 1st Election } & 0.175 & 0.175 & 0.164 & 0.175 & 0.171 & 0.178 & 0.303 & 0.175 & 0.143 & 0.171 & 0.176 & 0.180 & 0.182 & 0.181 & 0.206 \\
\hline & $(0.114)$ & $(0.225)$ & $(0.220)$ & $(0.114)$ & $(0.114)$ & $(0.114)$ & $(0.293)$ & $(0.114)$ & $(0.113)$ & $(0.115)$ & $(0.114)$ & $(0.115)$ & $(0.115)$ & $(0.114)$ & $(0.112)$ \\
\hline Obs & 5,208 & 1,752 & 1,752 & 5,208 & 5,208 & 5,208 & 1,297 & 5,208 & 5,064 & 5,208 & 5,208 & 5,208 & 5,208 & 5,208 & 5,208 \\
\hline \multirow[t]{2}{*}{$\mathrm{R}^{2}$} & 0.199 & 0.202 & 0.202 & 0.199 & 0.201 & 0.205 & 0.197 & 0.199 & 0.204 & 0.201 & 0.206 & 0.204 & 0.202 & 0.201 & 0.231 \\
\hline & \multicolumn{15}{|c|}{ F. Dependent Variable: Ln Public Investment in Irrigation from Village Funds } \\
\hline \multirow{2}{*}{$\begin{array}{l}\text { Post 1st Election x Avg } \\
\text { Ln HH Farmland }\end{array}$} & 0.237 & & & 0.236 & 0.238 & 0.217 & 0.227 & & 0.226 & 0.239 & 0.231 & 0.238 & 0.225 & 0.232 & 0.215 \\
\hline & $(0.160)$ & & & $(0.160)$ & $(0.161)$ & $(0.156)$ & $(0.164)$ & & $(0.160)$ & $(0.156)$ & $(0.159)$ & $(0.162)$ & $(0.161)$ & $(0.161)$ & $(0.159)$ \\
\hline Obs & 5,208 & & & 5,208 & 5,208 & 5,208 & 5,208 & & 5,064 & 5,208 & 5,208 & 5,208 & 5,208 & 5,208 & 5,208 \\
\hline \multirow[t]{2}{*}{$\mathrm{R}^{2}$} & 0.102 & & & 0.106 & 0.110 & 0.110 & 0.114 & & 0.109 & 0.108 & 0.108 & 0.111 & 0.109 & 0.107 & 0.137 \\
\hline & \multicolumn{15}{|c|}{ G. Dependent Variable: Ln Public Investment in Schools from Village Funds ${ }^{\star \star}$} \\
\hline \multirow{2}{*}{$\begin{array}{l}\text { Post 1st Election x \# of } \\
\text { Kids 7-13 }\end{array}$} & 0.015 & & & 0.015 & 0.015 & 0.014 & 0.016 & & 0.015 & 0.016 & 0.015 & 0.015 & 0.015 & 0.022 & 0.013 \\
\hline & $(0.006)$ & & & $(0.006)$ & $(0.006)$ & $(0.006)$ & $(0.006)$ & & $(0.006)$ & $(0.006)$ & $(0.006)$ & $(0.005)$ & $(0.006)$ & $(0.008)$ & $(0.005)$ \\
\hline Obs & 5,064 & & & 5,064 & 5,064 & 5,064 & 5,064 & & 5,064 & 5,064 & 5,064 & 5,064 & 5,064 & 3,001 & 5,064 \\
\hline $\mathrm{R}^{2}$ & 0.069 & & & 0.069 & 0.072 & 0.076 & 0.072 & & 0.074 & 0.071 & 0.072 & 0.077 & 0.073 & 0.107 & 0.098 \\
\hline
\end{tabular}

Notes: All regressions control for province-time trends, village and year fixed effects. The regressions in Panels $F$ and $G$ also control for the interaction of the relevant village characteristic (e.g., number of kids age 7-13, log total household farmland) with post first competitive election and post first open nominations. Standard errors are clustered at the village level. * For outcomes in Panels C-G, we do not control for the starred (*) land and household fee 217 villages. 
Table 9: The Effect of Elections - Robustness to Additional Factors

\begin{tabular}{|c|c|c|c|c|c|c|c|}
\hline & \multicolumn{7}{|c|}{ Dependent Variables } \\
\hline & $\begin{array}{c}\text { Baseline } \\
\text { (1) }\end{array}$ & $\begin{array}{c}\text { Election } \\
\text { Procedures } \\
\\
(2)\end{array}$ & $\begin{array}{c}\text { Size of } \\
\text { Largest } \\
\text { Clan } x \\
\text { Year FE } \\
\text { (3) }\end{array}$ & $\begin{array}{c}\text { Family } \\
\text { Tree or } \\
\text { Ancestral } \\
\text { Temple } x \\
\text { Year FE } \\
(4)\end{array}$ & $\begin{array}{l}\text { Post Tax } \\
\text { \& Fee } \\
\text { Reform } \\
\\
(5)\end{array}$ & $\begin{array}{l}\text { Ever } \\
\text { Merged } \\
\text { with } \\
\text { Another } \\
\text { Village } \\
(6) \\
\end{array}$ & $\begin{array}{c}\text { All } \\
\text { controls } \\
(7) \\
\end{array}$ \\
\hline & \multicolumn{7}{|c|}{ A. Ln Median HH Land } \\
\hline Post 1st Election & $\begin{array}{c}0.253 \\
(0.117)\end{array}$ & $\begin{array}{c}0.318 \\
(0.150)\end{array}$ & $\begin{array}{c}0.257 \\
(0.118)\end{array}$ & $\begin{array}{c}0.252 \\
(0.116)\end{array}$ & $\begin{array}{c}0.249 \\
(0.115)\end{array}$ & $\begin{array}{c}0.271 \\
(0.119)\end{array}$ & $\begin{array}{c}0.304 \\
(0.141)\end{array}$ \\
\hline Observations & 1,297 & 1,297 & 1,297 & 1,297 & 1,297 & 1,297 & 1,297 \\
\hline \multirow[t]{2}{*}{$\mathrm{R}^{2}$} & 0.884 & 0.889 & 0.885 & 0.889 & 0.887 & 0.886 & 0.897 \\
\hline & \multicolumn{7}{|c|}{ B. Ln Median HH Fees and Levies } \\
\hline Post 1st Election & $\begin{array}{c}0.956 \\
(0.503)\end{array}$ & $\begin{array}{c}0.875 \\
(0.529)\end{array}$ & $\begin{array}{c}0.962 \\
(0.508)\end{array}$ & $\begin{array}{c}1.015 \\
(0.515)\end{array}$ & $\begin{array}{c}0.969 \\
(0.506)\end{array}$ & $\begin{array}{c}0.910 \\
(0.524)\end{array}$ & $\begin{array}{c}0.991 \\
(0.575)\end{array}$ \\
\hline Observations & 1,297 & 1,297 & 1,297 & 1,297 & 1,297 & 1,297 & 1,297 \\
\hline \multirow[t]{2}{*}{$\mathrm{R}^{2}$} & 0.610 & 0.614 & 0.614 & 0.622 & 0.613 & 0.615 & 0.638 \\
\hline & \multicolumn{7}{|c|}{ C. Upper Government Land Expropriation } \\
\hline Post 1st Election & $\begin{array}{l}-0.018 \\
(0.011)\end{array}$ & $\begin{array}{l}-0.019 \\
(0.013)\end{array}$ & $\begin{array}{l}-0.017 \\
(0.011)\end{array}$ & $\begin{array}{l}-0.016 \\
(0.011)\end{array}$ & $\begin{array}{l}-0.018 \\
(0.011)\end{array}$ & $\begin{array}{l}-0.017 \\
(0.011)\end{array}$ & $\begin{array}{l}-0.016 \\
(0.013)\end{array}$ \\
\hline Observations & 5,208 & 5,208 & 5,208 & 5,208 & 5,208 & 5,208 & 5,208 \\
\hline \multirow[t]{2}{*}{$\mathrm{R}^{2}$} & 0.08 & 0.081 & 0.084 & 0.09 & 0.08 & 0.084 & 0.099 \\
\hline & \multicolumn{7}{|c|}{ D. Dummy for Allowing a 2nd Child if the 1 st is a Girl } \\
\hline Post 1st Election & $\begin{array}{c}0.082 \\
(0.040)\end{array}$ & $\begin{array}{c}0.077 \\
(0.042)\end{array}$ & $\begin{array}{c}0.087 \\
(0.039)\end{array}$ & $\begin{array}{c}0.083 \\
(0.039)\end{array}$ & $\begin{array}{c}0.082 \\
(0.040)\end{array}$ & $\begin{array}{c}0.090 \\
(0.040)\end{array}$ & $\begin{array}{c}0.087 \\
(0.042)\end{array}$ \\
\hline Observations & 5,208 & 5,208 & 5,208 & 5,208 & 5,208 & 5,208 & 5,208 \\
\hline \multirow[t]{2}{*}{$\mathrm{R}^{2}$} & 0.755 & 0.755 & 0.756 & 0.756 & 0.755 & 0.758 & 0.761 \\
\hline & \multicolumn{7}{|c|}{ E. Ln Total Public Investment } \\
\hline Post 1st Election & $\begin{array}{c}0.175 \\
(0.114)\end{array}$ & $\begin{array}{c}0.189 \\
(0.127)\end{array}$ & $\begin{array}{c}0.173 \\
(0.116)\end{array}$ & $\begin{array}{c}0.178 \\
(0.115)\end{array}$ & $\begin{array}{c}0.175 \\
(0.114)\end{array}$ & $\begin{array}{c}0.174 \\
(0.115)\end{array}$ & $\begin{array}{l}0.198 \\
(0.131)\end{array}$ \\
\hline Observations & 5,208 & 5,208 & 5,208 & 5,208 & 5,208 & 5,208 & 5,208 \\
\hline \multirow[t]{2}{*}{$\mathrm{R}^{2}$} & 0.199 & 0.199 & 0.202 & 0.208 & 0.199 & 0.202 & 0.214 \\
\hline & \multicolumn{7}{|c|}{ F. Ln Public Investment into Irrigation (from Village Funds) } \\
\hline $\begin{array}{l}\text { Post 1st Election } x \\
\text { Avg Ln HH Farmland }\end{array}$ & $\begin{array}{c}0.236 \\
(0.160)\end{array}$ & $\begin{array}{c}0.246 \\
(0.164)\end{array}$ & $\begin{array}{c}0.235 \\
(0.160)\end{array}$ & $\begin{array}{c}0.260 \\
(0.163)\end{array}$ & $\begin{array}{c}0.240 \\
(0.159)\end{array}$ & $\begin{array}{c}0.239 \\
(0.160)\end{array}$ & $\begin{array}{c}0.275 \\
(0.168)\end{array}$ \\
\hline Observations & 5,208 & 5,208 & 5,208 & 5,208 & 5,208 & 5,208 & 5,208 \\
\hline \multirow[t]{2}{*}{$\mathrm{R}^{2}$} & 0.106 & 0.106 & 0.109 & 0.113 & 0.106 & 0.109 & 0.12 \\
\hline & \multicolumn{7}{|c|}{ G. Ln Public Investment into Schooling (from Village Funds) ${ }^{*}$} \\
\hline $\begin{array}{l}\text { Post 1st Election } x \\
\text { \# of Kids } 7-13\end{array}$ & $\begin{array}{c}0.015 \\
(0.006)\end{array}$ & $\begin{array}{c}0.015 \\
(0.006)\end{array}$ & $\begin{array}{c}0.015 \\
(0.006)\end{array}$ & $\begin{array}{c}0.015 \\
(0.005)\end{array}$ & $\begin{array}{c}0.016 \\
(0.006)\end{array}$ & $\begin{array}{c}0.015 \\
(0.006)\end{array}$ & $\begin{array}{l}0.014 \\
(0.006)\end{array}$ \\
\hline Observations & 5,064 & 5,064 & 5,064 & 5,064 & 5,064 & 5,064 & 5,064 \\
\hline $\mathrm{R}^{2}$ & 0.069 & 0.07 & 0.073 & 0.083 & 0.069 & 0.072 & 0.09 \\
\hline
\end{tabular}

Notes: *The coefficients for the estimates on public investment in schooling are scaled by 1,000 for ease of interpretation. All regressions control for province-time trends, village and year fixed effects. The regressions in Panels $F$ and $G$ also control for the interaction of the relevant village characteristic (e.g., number of kids age 7-13, log total household farm land) with post first competitive election and post first open nominations. Standard errors are clustered at the village level. . Panels A and B use data from the 72 subsample. Panels C-G use the full sample of 217 villages. 
Table 10: The Effect of Elections - Robustness to the Omission of Villages that Introduced Elections Before 1987

\begin{tabular}{|c|c|c|c|c|c|c|c|c|}
\hline & \multicolumn{8}{|c|}{ Dependent Variables } \\
\hline & $\begin{array}{c}\text { Baseline } \\
\text { Sample } \\
\text { (1) }\end{array}$ & $\begin{array}{c}\text { Omit if 1st } \\
\text { Election } \\
<1987 \\
(2)\end{array}$ & $\begin{array}{c}\text { Baseline } \\
\text { Sample } \\
\text { (3) }\end{array}$ & $\begin{array}{c}\text { Omit if 1st } \\
\text { Election } \\
<1987 \\
(4)\end{array}$ & $\begin{array}{c}\text { Baseline } \\
\text { Sample } \\
\text { (5) }\end{array}$ & $\begin{array}{l}\text { Omit if 1st } \\
\text { Election } \\
<1987 \\
(6)\end{array}$ & $\begin{array}{c}\text { Baseline } \\
\text { Sample } \\
(7)\end{array}$ & $\begin{array}{c}\text { Omit if 1st } \\
\text { Election } \\
<1987 \\
(8)\end{array}$ \\
\hline & \multicolumn{8}{|c|}{ Panel A. } \\
\hline & \multicolumn{2}{|c|}{ Ln Median HH Land } & \multicolumn{2}{|c|}{ Ln Median HH Fees } & \multicolumn{2}{|c|}{$\begin{array}{l}\text { Upper Government Land } \\
\text { Expropriation }\end{array}$} & \multicolumn{2}{|c|}{$\begin{array}{l}\text { Dummy for Allowing a } \\
\text { 2nd Child if the 1st is a } \\
\text { Girl }\end{array}$} \\
\hline Observations & 1,297 & 1,152 & 1,297 & 1,152 & 5,208 & 3,906 & 5,208 & 3,906 \\
\hline \multirow[t]{4}{*}{$\mathrm{R}^{2}$} & 0.884 & 0.896 & 0.610 & 0.625 & 0.080 & 0.089 & 0.755 & 0.820 \\
\hline & \multicolumn{8}{|c|}{ Panel B } \\
\hline & \multicolumn{2}{|c|}{$\begin{array}{l}\text { Ln Total Public } \\
\text { Investment }\end{array}$} & \multicolumn{2}{|c|}{$\begin{array}{l}\text { Ln Public Investment in } \\
\text { Schooling from Villagers }\end{array}$} & \multicolumn{2}{|c|}{$\begin{array}{l}\text { Ln Public Investment in } \\
\text { Irrigation from Villagers }\end{array}$} & & \\
\hline & $\begin{array}{l}\text { Baseline } \\
\text { Sample }\end{array}$ & $\begin{array}{l}\text { Omit if 1st } \\
\text { Election } \\
<1987\end{array}$ & $\begin{array}{l}\text { Baseline } \\
\text { Sample }\end{array}$ & $\begin{array}{l}\text { Omit if 1st } \\
\text { Election } \\
<1987\end{array}$ & $\begin{array}{l}\text { Baseline } \\
\text { Sample }\end{array}$ & $\begin{array}{l}\text { Omit if 1st } \\
\text { Election } \\
<1987\end{array}$ & & \\
\hline Post 1st Election & $\begin{array}{c}0.175 \\
(0.114)\end{array}$ & $\begin{array}{c}0.340 \\
(0.172)\end{array}$ & $\begin{array}{c}6.273 \\
(13.470)\end{array}$ & $\begin{array}{c}11.160 \\
(18.640)\end{array}$ & $\begin{array}{l}-1.599 \\
(1.191)\end{array}$ & $\begin{array}{l}-1.788 \\
(1.855)\end{array}$ & & \\
\hline Post 1st Election $\mathrm{x} \#$ of Kids 7-13 & & & $\begin{array}{c}0.015 \\
(0.006)\end{array}$ & $\begin{array}{c}0.015 \\
(0.010)\end{array}$ & & & & \\
\hline Post 1st Election x Avg Ln HH Farmland & & & & & $\begin{array}{c}0.236 \\
(0.160)\end{array}$ & $\begin{array}{c}0.286 \\
(0.243)\end{array}$ & & \\
\hline Observations & 5,208 & 3,906 & 5,064 & 3,798 & 5,208 & 3,906 & & \\
\hline $\mathrm{R}^{2}$ & 0.199 & 0.194 & 0.069 & 0.085 & 0.106 & 0.126 & & \\
\hline
\end{tabular}

Notes: All regressions control for the introduction of the first competitive election and open nominations, province-year trends, village and year fixed effects. Regressions in Panel B also control for the interactions of those electoral reforms with the relevant village characteristics (e.g., \# of kids 7-13, average log total household far land). The standard errors are clustered at the village level. Panel A columns (1)-(4) use data from the 72 village subsample. All other regressions use the full sample of 217 villages. 
Figure 1: The Correlation between the Introduction of Elections and the Power to Unilaterally Appoint Village Enterprise Manager

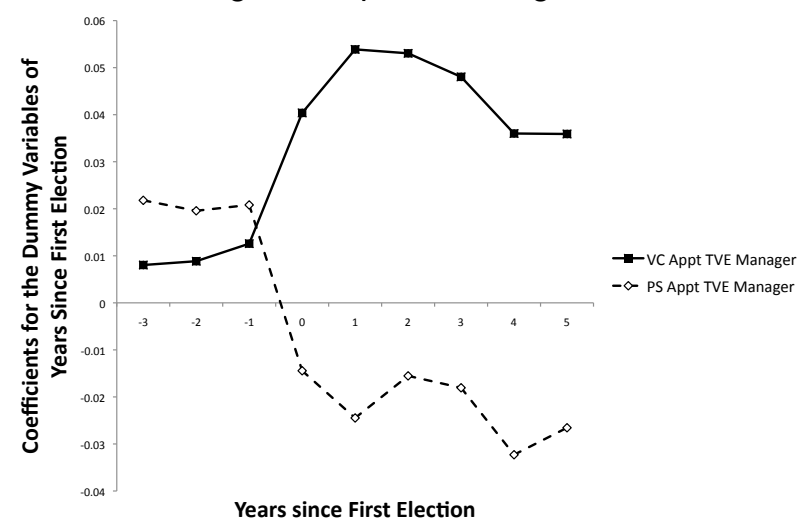

Figure 2: The Correlation between the Introduction of Elections and One Child Policy Exemptions

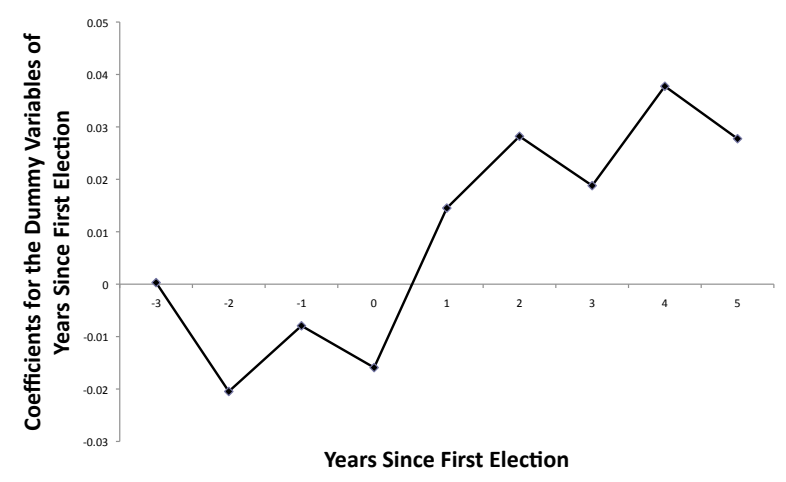

Figure 3: The Correlation between the Introduction of Elections and Median Household Land Allocation

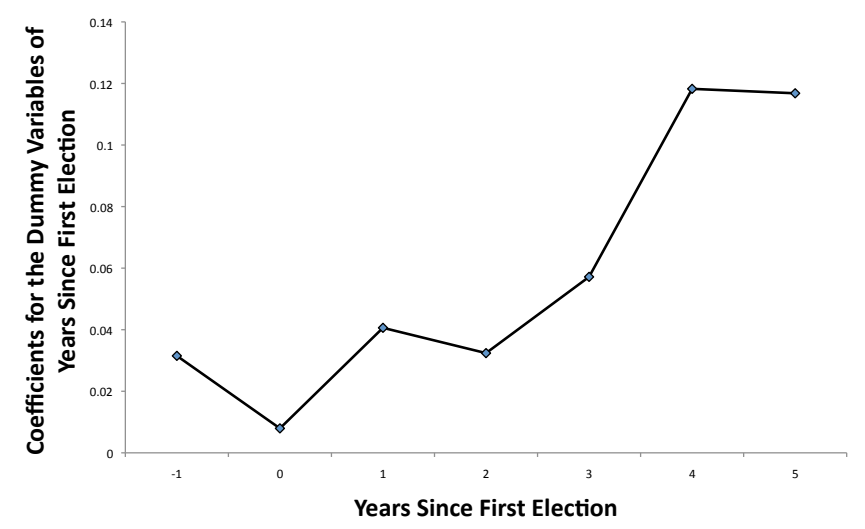


APPENDIX Table A1: Household and Village Government Balance Sheet

\begin{tabular}{|c|c|c|c|}
\hline & Obs & Mean & Std. Dev. \\
\hline \multicolumn{4}{|c|}{ A. Households } \\
\hline Total Income & 1,297 & 15,658 & 19,746 \\
\hline from collectives & 1,296 & 375 & 814 \\
\hline from $\mathrm{HH}$ management & 1,297 & 10,433 & 13,176 \\
\hline from wages & 1,297 & 2,546 & 3,720 \\
\hline other & 1,297 & 1,344 & 3,240 \\
\hline Total Expenditures & 1,297 & 13,324 & 17,480 \\
\hline Household management expenditures & 1,297 & 4,777 & 10,151 \\
\hline Levies and Fees to county and village governments & 1,297 & 454 & 530 \\
\hline Total Consumption & 1,297 & 7,385 & 8,126 \\
\hline food & 1,297 & 3,169 & 2,344 \\
\hline grain food & 1,297 & 1,020 & 479 \\
\hline non-grain food & 1,297 & 1,702 & 1,655 \\
\hline clothes & 1,297 & 432 & 356 \\
\hline house & 1,297 & 1,308 & 2,383 \\
\hline fuel & 1,297 & 238 & 159 \\
\hline living services & 1,297 & 487 & 622 \\
\hline tuition & 1,297 & 655 & 691 \\
\hline other & 1,297 & 742 & 1,139 \\
\hline \multicolumn{4}{|c|}{ B. Village Governments } \\
\hline Total Revenues (100 RMB) & 4,773 & 3,564 & 32,250 \\
\hline from collectives & 4,773 & 1,802 & 24,526 \\
\hline from $\mathrm{HH}^{*}$ & 4,773 & 642 & 8,226 \\
\hline Total Expenditures (100 RMB) & 4,773 & 3,388 & 34,304 \\
\hline collective production* & 4,773 & 1,192 & 27,574 \\
\hline delivery to upper levels of gov & 4,773 & 296 & 1,808 \\
\hline public affairs & 4,773 & 279 & 1,206 \\
\hline Administrative Expenditures ${ }^{*}$ & 4,773 & 210 & 781 \\
\hline
\end{tabular}

Notes: The data in panel A are obtained from household-level data for 72 villages. The average income and expenditure are computed together with their corresponding subcategories for each village and year. In panel $B$, the data are from the NFS village surveys for 217 villages. The time coverage for both panel A and B are 1987-2005 (with the exception of years 1992 and 1994 , during which the survey was not conducted). ${ }^{*}$ The time coverage of these variables is 1987-2002. Other components of fiscal revenues are payments for obligated working days bought off, tax revenue from firm, transfers from upper levels of government and miscellaneous revenue. Other components of village expenditure are expenses on household production. We do not report summary statistics for these variables because they are not systematically reported until 1993. 
Table A2: Reform Timing

\begin{tabular}{|c|c|c|c|c|c|c|}
\hline \multirow[b]{2}{*}{ Year } & \multicolumn{2}{|c|}{ First Election } & \multicolumn{2}{|c|}{$\begin{array}{c}\text { First Competitive Election (with }>1 \\
\text { Candidate) }\end{array}$} & \multicolumn{2}{|c|}{ First Open Nominations } \\
\hline & $\begin{array}{l}\text { Number of } \\
\text { Villages } \\
\text { Introducing } \\
(1) \\
\end{array}$ & $\begin{array}{c}\text { Cumulative \% } \\
\text { of Villages } \\
(2)\end{array}$ & $\begin{array}{c}\text { Number of } \\
\text { Villages } \\
\text { Introducing } \\
(3)\end{array}$ & $\begin{array}{c}\text { Cumulative \% } \\
\text { of Villages } \\
(4)\end{array}$ & $\begin{array}{c}\text { Number of } \\
\text { Villages } \\
\text { Introducing } \\
(5) \\
\end{array}$ & $\begin{array}{c}\text { Cumulative \% } \\
\text { of Villages } \\
(6)\end{array}$ \\
\hline 1982 & 13 & 5.99 & 10 & 4.69 & 1 & 0.72 \\
\hline 1983 & 13 & 11.98 & 7 & 7.98 & 1 & 1.44 \\
\hline 1984 & 42 & 31.34 & 29 & 21.6 & 7 & 6.47 \\
\hline 1985 & 3 & 32.72 & 1 & 22.07 & 0 & 6.47 \\
\hline 1986 & 35 & 48.85 & 19 & 30.99 & 4 & 9.35 \\
\hline 1987 & 12 & 54.38 & 6 & 33.8 & 1 & 10.07 \\
\hline 1988 & 7 & 57.6 & 4 & 35.68 & 1 & 10.79 \\
\hline 1989 & 15 & 64.52 & 11 & 40.85 & 1 & 11.51 \\
\hline 1990 & 25 & 76.04 & 17 & 48.83 & 1 & 12.23 \\
\hline 1991 & 1 & 76.5 & 3 & 50.23 & 0 & 12.23 \\
\hline 1992 & 3 & 77.88 & 5 & 52.58 & 1 & 12.95 \\
\hline 1993 & 6 & 80.65 & 6 & 55.4 & 3 & 15.11 \\
\hline 1994 & 2 & 81.57 & 5 & 57.75 & 3 & 17.27 \\
\hline 1995 & 9 & 85.71 & 8 & 61.5 & 3 & 19.42 \\
\hline 1996 & 4 & 87.56 & 13 & 67.61 & 18 & 32.37 \\
\hline 1997 & 3 & 88.94 & 4 & 69.48 & 0 & 32.37 \\
\hline 1998 & 6 & 91.71 & 7 & 72.77 & 6 & 36.69 \\
\hline 1999 & 9 & 95.85 & 37 & 90.14 & 42 & 66.91 \\
\hline 2000 & 7 & 99.08 & 8 & 93.9 & 12 & 75.54 \\
\hline 2001 & 2 & 100 & 6 & 96.71 & 12 & 84.17 \\
\hline 2002 & 0 & 100 & 5 & 99.06 & 11 & 92.09 \\
\hline 2003 & 0 & 100 & 0 & 99.06 & 3 & 94.24 \\
\hline 2004 & 0 & 100 & 2 & 100 & 1 & 94.96 \\
\hline 2005 & 0 & 100 & 0 & 100 & 7 & 100 \\
\hline Total & 217 & & 213 & & 139 & \\
\hline
\end{tabular}


Table A3: The Effect of Elections on Household Fees

\begin{tabular}{|c|c|c|c|c|c|c|c|c|c|}
\hline & \multicolumn{9}{|c|}{$\begin{array}{c}\text { Dependent Variables: Ln Levies and Fees paid to Village, and County (by deciles of the } \\
\text { within-village Distribution of Household Fees) }\end{array}$} \\
\hline & $\begin{array}{c}\text { 10th } \\
(1)\end{array}$ & $\begin{array}{c}20 \text { th } \\
(2)\end{array}$ & $\begin{array}{c}\text { 30th } \\
(3)\end{array}$ & $\begin{array}{c}\text { 40th } \\
(4)\end{array}$ & $\begin{array}{c}50 \text { th } \\
(5)\end{array}$ & $\begin{array}{c}\text { 60th } \\
(6)\end{array}$ & $\begin{array}{c}\text { 70th } \\
(7)\end{array}$ & $\begin{array}{c}\text { 80th } \\
(8)\end{array}$ & $\begin{array}{c}\text { 90th } \\
(9)\end{array}$ \\
\hline Post 1st Election & $\begin{array}{l}1.027 \\
(0.450)\end{array}$ & $\begin{array}{l}0.797 \\
(0.468)\end{array}$ & $\begin{array}{l}0.765 \\
(0.449)\end{array}$ & $\begin{array}{l}0.930 \\
(0.473)\end{array}$ & $\begin{array}{l}0.956 \\
(0.503)\end{array}$ & $\begin{array}{c}0.971 \\
(0.506)\end{array}$ & $\begin{array}{c}1.069 \\
(0.522)\end{array}$ & $\begin{array}{c}0.922 \\
(0.480)\end{array}$ & $\begin{array}{c}0.539 \\
(0.401)\end{array}$ \\
\hline Post 1st Competitive Election & $\begin{array}{l}-0.062 \\
(0.381)\end{array}$ & $\begin{array}{l}-0.269 \\
(0.381)\end{array}$ & $\begin{array}{l}-0.085 \\
(0.342)\end{array}$ & $\begin{array}{l}-0.080 \\
(0.354)\end{array}$ & $\begin{array}{l}-0.109 \\
(0.344)\end{array}$ & $\begin{array}{l}-0.102 \\
(0.355)\end{array}$ & $\begin{array}{l}-0.268 \\
(0.363)\end{array}$ & $\begin{array}{l}-0.390 \\
(0.369)\end{array}$ & $\begin{array}{l}-0.452 \\
(0.367)\end{array}$ \\
\hline Post 1st Open Nomination & $\begin{array}{c}0.103 \\
(0.389)\end{array}$ & $\begin{array}{l}-0.131 \\
(0.384)\end{array}$ & $\begin{array}{l}-0.064 \\
(0.416)\end{array}$ & $\begin{array}{c}0.086 \\
(0.373)\end{array}$ & $\begin{array}{c}0.234 \\
(0.362)\end{array}$ & $\begin{array}{c}0.140 \\
(0.376)\end{array}$ & $\begin{array}{c}0.109 \\
(0.381)\end{array}$ & $\begin{array}{c}0.079 \\
(0.397)\end{array}$ & $\begin{array}{c}0.011 \\
(0.400)\end{array}$ \\
\hline Observations & 1,297 & 1,297 & 1,297 & 1,297 & 1,297 & 1,297 & 1,297 & 1,297 & 1,297 \\
\hline R-squared & 0.556 & 0.572 & 0.596 & 0.586 & 0.61 & 0.607 & 0.611 & 0.618 & 0.586 \\
\hline
\end{tabular}

Notes: All regressions control for province-time trends, village and year fixed effects. Standard errors are clustered at the village level. These regressions use the 72 -village subsample.

Table A4: The Effect of Elections on Household Income by Source

\begin{tabular}{|c|c|c|c|c|c|c|}
\hline & \multicolumn{2}{|c|}{ Dependent Variables } & \multicolumn{2}{|c|}{ Post 1st Election } & \multirow[b]{2}{*}{ Obs } & \multirow[b]{2}{*}{$\mathrm{R}^{2}$} \\
\hline & & & Coeff & SE & & \\
\hline (1) & \multirow{6}{*}{$\begin{array}{c}\text { Ln Total HH } \\
\text { Gross } \\
\text { Income }\end{array}$} & p10 & 0.028 & $(0.130)$ & 1,297 & 0.496 \\
\hline (2) & & p25 & -0.021 & $(0.051)$ & 1,297 & 0.876 \\
\hline (3) & & p50 & -0.055 & $(0.043)$ & 1,297 & 0.903 \\
\hline (4) & & p75 & -0.082 & $(0.051)$ & 1,297 & 0.901 \\
\hline (5) & & p90 & -0.096 & $(0.068)$ & 1,297 & 0.884 \\
\hline (6) & & Mean & -0.077 & $(0.060)$ & 1,297 & 0.893 \\
\hline (7) & \multirow{6}{*}{$\begin{array}{c}\text { Ln HH } \\
\text { Income from } \\
\text { Village } \\
\text { Enterprises }\end{array}$} & p10 & & & & \\
\hline (8) & & p25 & & & & \\
\hline (9) & & p50 & 0.015 & $(0.024)$ & 870 & 0.107 \\
\hline (10) & & p75 & -0.292 & $(0.341)$ & 870 & 0.257 \\
\hline (11) & & p90 & -1.421 & $(0.966)$ & 870 & 0.290 \\
\hline (12) & & Mean & -1.208 & (1.003) & 868 & 0.460 \\
\hline (13) & \multirow{6}{*}{$\begin{array}{c}\mathrm{Ln} \mathrm{HH} \\
\text { Income from } \\
\text { Wages }\end{array}$} & p10 & 0.146 & $(0.134)$ & 1,297 & 0.185 \\
\hline (14) & & p25 & 0.496 & $(0.562)$ & 1,297 & 0.473 \\
\hline (15) & & p50 & -0.920 & $(0.653)$ & 1,297 & 0.556 \\
\hline (16) & & p75 & -1.718 & $(0.622)$ & 1,297 & 0.549 \\
\hline (17) & & p90 & -0.547 & $(0.321)$ & 1,297 & 0.603 \\
\hline (18) & & Mean & -0.377 & $(0.151)$ & 1,297 & 0.736 \\
\hline (19) & \multirow{6}{*}{$\begin{array}{c}\text { Ln Total HH } \\
\text { Consumption }\end{array}$} & p10 & 0.030 & $(0.126)$ & 1,297 & 0.527 \\
\hline (20) & & p25 & -0.025 & $(0.058)$ & 1,297 & 0.890 \\
\hline (21) & & p50 & -0.050 & $(0.054)$ & 1,297 & 0.904 \\
\hline (22) & & p75 & -0.081 & $(0.057)$ & 1,297 & 0.899 \\
\hline (23) & & p90 & -0.106 & $(0.070)$ & 1,297 & 0.864 \\
\hline (24) & & Mean & -0.086 & $(0.063)$ & 1,297 & 0.895 \\
\hline
\end{tabular}

Notes: All regressions control for province-time trends, village and year fixed effects. Standard errors are clustered at the village level. These regressions use the 72-village subsample. 


\section{Table A5: Correlation between the Years since the Introduction of Elections and Outcomes}

\begin{tabular}{|c|c|c|c|c|c|c|c|c|c|c|c|c|}
\hline \multirow[b]{3}{*}{$\begin{array}{l}\text { Years since } \\
\text { 1st Election } \\
\text { Dummy } \\
\text { Variables }\end{array}$} & \multicolumn{12}{|c|}{ Dependent Variables } \\
\hline & \multicolumn{5}{|c|}{ Village Chief } & \multicolumn{5}{|c|}{$\begin{array}{ll}\text { Party Secretary } \\
\end{array}$} & \multirow[b]{2}{*}{$\begin{array}{c}\text { OCP } \\
\text { Exempt } \\
(16)\end{array}$} & \multirow[b]{2}{*}{$\begin{array}{c}\text { Ln } \\
\text { Median } \\
\text { HH } \\
\text { Land } \\
(17)\end{array}$} \\
\hline & $\begin{array}{c}\text { Appt } \\
\text { TVE } \\
\text { Manager } \\
\\
(1)\end{array}$ & $\begin{array}{c}\text { Employ } \\
\text { Staff }\end{array}$ & Reimburse & $\begin{array}{l}\text { Land Re- } \\
\text { allocation } \\
\text { (4) }\end{array}$ & $\begin{array}{l}\text { Public } \\
\text { Inv } \\
\text { (5) }\end{array}$ & $\begin{array}{c}\text { Appt } \\
\text { TVE } \\
\text { Manager } \\
\\
(11)\end{array}$ & $\begin{array}{c}\text { Employ } \\
\text { Staff } \\
(12)\end{array}$ & (13) & $\begin{array}{l}\text { Land Re- } \\
\text { allocation } \\
\text { (14) }\end{array}$ & $\begin{array}{l}\text { Public } \\
\text { Inv } \\
(15)\end{array}$ & & \\
\hline Dummy -3 & $\begin{array}{c}0.008 \\
(0.017)\end{array}$ & $\begin{array}{c}0.027 \\
(0.019)\end{array}$ & $\begin{array}{c}0.013 \\
(0.016)\end{array}$ & $\begin{array}{c}0.018 \\
(0.018)\end{array}$ & $\begin{array}{l}-0.004 \\
(0.013)\end{array}$ & $\begin{array}{c}0.022 \\
(0.019)\end{array}$ & $\begin{array}{l}-0.004 \\
(0.019)\end{array}$ & $\begin{array}{c}0.012 \\
(0.015)\end{array}$ & $\begin{array}{c}0.025 \\
(0.016)\end{array}$ & $\begin{array}{c}0.016 \\
(0.016)\end{array}$ & $\begin{array}{l}0.0003 \\
(0.029)\end{array}$ & \\
\hline Dummy -2 & $\begin{array}{c}0.009 \\
(0.017)\end{array}$ & $\begin{array}{c}0.031 \\
(0.018)\end{array}$ & $\begin{array}{c}0.021 \\
(0.018)\end{array}$ & $\begin{array}{c}0.032 \\
(0.017)\end{array}$ & $\begin{array}{c}0.008 \\
(0.012)\end{array}$ & $\begin{array}{c}0.020 \\
(0.023)\end{array}$ & $\begin{array}{l}-0.009 \\
(0.021)\end{array}$ & $\begin{array}{c}0.005 \\
(0.016)\end{array}$ & $\begin{array}{c}0.019 \\
(0.018)\end{array}$ & $\begin{array}{c}0.014 \\
(0.018)\end{array}$ & $\begin{array}{l}-0.021 \\
(0.029)\end{array}$ & \\
\hline Dummy -1 & $\begin{array}{c}0.013 \\
(0.018)\end{array}$ & $\begin{array}{c}0.037 \\
(0.019)\end{array}$ & $\begin{array}{c}0.029 \\
(0.021)\end{array}$ & $\begin{array}{c}0.043 \\
(0.018)\end{array}$ & $\begin{array}{c}0.011 \\
(0.012)\end{array}$ & $\begin{array}{c}0.021 \\
(0.023)\end{array}$ & $\begin{array}{c}0.000 \\
(0.021)\end{array}$ & $\begin{array}{l}-0.005 \\
(0.018)\end{array}$ & $\begin{array}{c}0.021 \\
(0.019)\end{array}$ & $\begin{array}{c}0.017 \\
(0.018)\end{array}$ & $\begin{array}{l}-0.008 \\
(0.030)\end{array}$ & $\begin{array}{c}0.032 \\
(0.065)\end{array}$ \\
\hline Dummy 0 & $\begin{array}{c}0.040 \\
(0.024)\end{array}$ & $\begin{array}{c}0.032 \\
(0.021)\end{array}$ & $\begin{array}{c}0.049 \\
(0.021)\end{array}$ & $\begin{array}{c}0.050 \\
(0.018)\end{array}$ & $\begin{array}{c}0.037 \\
(0.014)\end{array}$ & $\begin{array}{l}-0.014 \\
(0.025)\end{array}$ & $\begin{array}{c}0.002 \\
(0.022)\end{array}$ & $\begin{array}{l}-0.038 \\
(0.016)\end{array}$ & $\begin{array}{l}-0.031 \\
(0.018)\end{array}$ & $\begin{array}{l}-0.036 \\
(0.018)\end{array}$ & $\begin{array}{l}-0.016 \\
(0.031)\end{array}$ & $\begin{array}{c}0.008 \\
(0.054)\end{array}$ \\
\hline Dummy +1 & $\begin{array}{c}0.054 \\
(0.024)\end{array}$ & $\begin{array}{c}0.036 \\
(0.020)\end{array}$ & $\begin{array}{c}0.051 \\
(0.021)\end{array}$ & $\begin{array}{c}0.061 \\
(0.019)\end{array}$ & $\begin{array}{c}0.041 \\
(0.016)\end{array}$ & $\begin{array}{l}-0.025 \\
(0.027)\end{array}$ & $\begin{array}{c}0.001 \\
(0.023)\end{array}$ & $\begin{array}{l}-0.030 \\
(0.017)\end{array}$ & $\begin{array}{l}-0.023 \\
(0.018)\end{array}$ & $\begin{array}{l}-0.025 \\
(0.017)\end{array}$ & $\begin{array}{c}0.015 \\
(0.031)\end{array}$ & $\begin{array}{c}0.041 \\
(0.055)\end{array}$ \\
\hline Dummy +2 & $\begin{array}{c}0.053 \\
(0.024)\end{array}$ & $\begin{array}{c}0.045 \\
(0.021)\end{array}$ & $\begin{array}{c}0.049 \\
(0.021)\end{array}$ & $\begin{array}{c}0.080 \\
(0.021)\end{array}$ & $\begin{array}{c}0.050 \\
(0.017)\end{array}$ & $\begin{array}{l}-0.016 \\
(0.027)\end{array}$ & $\begin{array}{c}0.000 \\
(0.022)\end{array}$ & $\begin{array}{l}-0.025 \\
(0.017)\end{array}$ & $\begin{array}{l}-0.021 \\
(0.018)\end{array}$ & $\begin{array}{l}-0.021 \\
(0.017)\end{array}$ & $\begin{array}{c}0.028 \\
(0.029)\end{array}$ & $\begin{array}{c}0.032 \\
(0.054)\end{array}$ \\
\hline Dummy +3 & $\begin{array}{c}0.048 \\
(0.023)\end{array}$ & $\begin{array}{c}0.037 \\
(0.020)\end{array}$ & $\begin{array}{c}0.054 \\
(0.020)\end{array}$ & $\begin{array}{c}0.058 \\
(0.019)\end{array}$ & $\begin{array}{c}0.043 \\
(0.017)\end{array}$ & $\begin{array}{l}-0.018 \\
(0.024)\end{array}$ & $\begin{array}{c}0.003 \\
(0.020)\end{array}$ & $\begin{array}{l}-0.028 \\
(0.016)\end{array}$ & $\begin{array}{l}-0.018 \\
(0.017)\end{array}$ & $\begin{array}{l}-0.011 \\
(0.016)\end{array}$ & $\begin{array}{c}0.019 \\
(0.029)\end{array}$ & $\begin{array}{c}0.057 \\
(0.056)\end{array}$ \\
\hline Dummy +4 & $\begin{array}{c}0.036 \\
(0.022)\end{array}$ & $\begin{array}{c}0.029 \\
(0.020)\end{array}$ & $\begin{array}{c}0.041 \\
(0.020)\end{array}$ & $\begin{array}{c}0.052 \\
(0.018)\end{array}$ & $\begin{array}{c}0.036 \\
(0.017)\end{array}$ & $\begin{array}{l}-0.032 \\
(0.022)\end{array}$ & $\begin{array}{l}-0.005 \\
(0.019)\end{array}$ & $\begin{array}{l}-0.033 \\
(0.016)\end{array}$ & $\begin{array}{l}-0.022 \\
(0.016)\end{array}$ & $\begin{array}{l}-0.015 \\
(0.016)\end{array}$ & $\begin{array}{c}0.038 \\
(0.027)\end{array}$ & $\begin{array}{c}0.118 \\
(0.052)\end{array}$ \\
\hline Dummy +5 & $\begin{array}{c}0.036 \\
(0.023)\end{array}$ & $\begin{array}{c}0.030 \\
(0.020)\end{array}$ & $\begin{array}{c}0.044 \\
(0.020)\end{array}$ & $\begin{array}{c}0.038 \\
(0.018)\end{array}$ & $\begin{array}{c}0.021 \\
(0.016)\end{array}$ & $\begin{array}{l}-0.027 \\
(0.020)\end{array}$ & $\begin{array}{l}-0.006 \\
(0.018)\end{array}$ & $\begin{array}{l}-0.034 \\
(0.015)\end{array}$ & $\begin{array}{l}-0.017 \\
(0.017)\end{array}$ & $\begin{array}{l}-0.008 \\
(0.017)\end{array}$ & $\begin{array}{c}0.028 \\
(0.023)\end{array}$ & $\begin{array}{c}0.117 \\
(0.062)\end{array}$ \\
\hline Observations & 3,336 & 4,103 & 4,910 & 3,936 & 4,457 & 3,336 & 4,103 & 4,910 & 3,936 & 4,457 & 5,208 & 1,297 \\
\hline $\mathrm{R}^{2}$ & 0.802 & 0.785 & 0.772 & 0.801 & 0.780 & 0.832 & 0.819 & 0.809 & 0.798 & 0.775 & 0.754 & 0.883 \\
\hline
\end{tabular}

Notes: All regressions control for post first competitive election, post first open nomination, province-time trends, village and year fixed effects. Standard errors are clustered at the village level. Columns (1)-(16) use data from the full 217 sample of villages. Column (17) uses data from the 72 -village subsample. 